\title{
RIZIK UNOVČENJA OBJEKTA LEASINGA U UGOVORU O OPERATIVNOM LEASINGU MOTORNOG VOZILA ${ }^{1}$
}

Dr. sc. Ivan Tot, poslijedoktorand

Ekonomski fakultet Sveučilišta u Zagrebu
UDK: 368.212

Ur.: 24. siječnja 2017.

Pr.: 8. veljače 2017.

Izvorni znanstveni rad

\begin{abstract}
Sažetak
Rad se bavi istraživanjem ugovora o operativnom leasingu motornog vozila u hrvatskoj poslovnoj praksi. Analiziraju se odredbe općih uvjeta poslovanja za ugovore o operativnom leasingu hrvatskih leasing društava, posebno one koje se odnose na prava i obveze ugovornih strana poslije prestanka ugovora o operativnom leasingu i vraćanja motornog vozila davatelju leasinga. Utvrđuje se postojanje tri modela ugovora o operativnom leasingu motornog vozila u hrvatskoj poslovnoj praksi koji se razlikuju međusobno prema kriteriju prijenosa $i$ raspodjele rizika unovčenja motornog vozila. Ti ugovorni modeli uspoređuju se s dva najčešća ugovorna modela ugovora o leasingu motornog vozila iz austrijske $i$ njemačke poslovne prakse: ugovorom s obračunom kilometraže i ugovorom s obračunom ostatka vrijednosti. Na temelju rezultata te usporedbe, ispituje se primjenjivost pojedinih pravnih rjě̌enja, razvijenih $u$ austrijskoj i njemačkoj sudskoj praksi i pravnoj književnosti u vezi s ugovorom s obračunom kilometraže i ugovorom s obračunom ostatka vrijednosti, na ugovor o operativnom leasingu motornog vozila u okvirima hrvatskog prava.
\end{abstract}

Ključne riječi: operativni leasing, leasing motornih vozila, rizik unovčenja, ostatak vrijednosti, ugovor s obračunom kilometraže, ugovor s obračunom ostatka vrijednosti.

\section{1. $U V O D$}

Posao operativnog leasinga uobičajeno se pravnotehnički realizira sklapanjem dva ugovora koja su gospodarski i pravno povezana prema zajedničkoj namjeri sva tri sudionika tog posla: (i) ugovora o kupoprodaji kojim davatelj leasinga kupuje objekt leasinga koji je izabrao primatelj leasinga od dobavljača objekta leasinga kojeg je izabrao primatelj leasinga, te (ii) ugovora o operativnom leasingu temeljem kojega primatelj leasinga stječe pravo uporabe objekta leasinga kroz određeno vremensko razdoblje uz obvezu plaćanja naknade za leasing davatelju leasinga. Ugovori o

1 U ovom se radu nastavlja istraživanje provedeno pri izradi doktorskog rada. Stoga se zahvaljujem mentoru, izv. prof. dr. sc. Hrvoju Markovinoviću, na svim savjetima koje mi je dao tijekom izrade doktorskog rada, a koje sam nastojao slijediti i pri izradi ovog rada. 
operativnom leasingu redovito se u poslovnoj praksi sklapaju na određeno vrijeme protekom kojega je primatelj leasinga obvezan vratiti objekt leasinga u posjed davatelju leasinga. Za posao operativnog leasinga karakteristično je da investicijske troškove koje je davatelj leasinga imao pri nabavi objekta leasinga on nadoknađuje dijelom putem naknade za leasing koju mu se obvezao platiti primatelj leasinga, a dijelom unovčenjem objekta leasinga nakon što mu je objekt leasinga vraćen po isteku ugovora o operativnom leasingu.

Naime, naknada za leasing se u ugovoru o operativnom leasingu uobičajeno računa uzimajući u obzir nabavnu vrijednost objekta leasinga te ugovoreno trajanje ugovora o operativnom leasingu. Pritom se od nabavne vrijednosti objekta leasinga oduzima iznos predvidivog ostatka vrijednosti objekta leasinga kojeg bi objekt leasinga trebao imati protekom ugovorenog trajanja ugovora. ${ }^{2}$ Investicijski rizik davatelja leasinga, odnosno rizik ulaganja i isplativosti ulaganja, obuhvaća gospodarske rizike i prilike da mu se novčana sredstva koja je on uložio u nabavu objekta leasinga koji odgovara potrebama primatelja leasinga vrate kroz prihode koje on ostvaruje u poslu leasinga i drugim poslovima poduzetim u vezi s nabavljenim objektom leasinga. $\mathrm{U}$ poslu operativnog leasinga investicijski rizik davatelja leasinga redovito se dijelom prenosi na primatelja leasinga, $\mathrm{i}$ to $\mathrm{u}$ onom opsegu u kojemu se nabavna vrijednost objekta leasinga nadoknađuje iz naknade za leasing koju se davatelju leasinga obvezao platiti primatelj leasinga. ${ }^{3}$ Preostali dio nabavne vrijednosti objekta leasinga, koji mu nije nadoknađen iz ugovorene naknade za leasing, davatelj leasinga nadoknađuje iz cijene postignute prodajom objekta leasinga po isteku ugovora o leasingu ili

2 Osim iznosa predvidivog ostatka vrijednosti objekta leasinga, od nabavne vrijednosti objekta leasinga oduzima se i iznos eventualnog predujma kojeg primatelj leasinga, ako se na to obvezao ugovorom o operativnom leasingu, plaća jednokratno odmah po sklapanju ugovora kao njegovo učešće u financiranju nabave objekta leasinga. Na opisani način izračunati iznos financiranja stavlja se u odnos prema ugovorenom trajanju ugovora o operativnom leasingu, čime se dolazi do iznosa pojedinog, najčešće mjesečnog, obroka naknade za leasing. Iznosi pojedinih obroka naknade za leasing uvećavaju se za ugovorne kamate primjenom ugovorene stope ugovornih kamata te za maržu davatelja leasinga. Zbroj pojedinih obroka naknade za leasing uvećanih za iznos ugovornih kamata i maržu, zajedno s jednokratnom naknadom koju prije sklapanja ugovora o operativnom leasingu primatelj leasinga plaća davatelju leasinga najčešće na ime "troška obrade ugovora", daje ukupnu neto naknadu za leasing u ugovoru o operativnom leasingu. Iz opisane metode izračuna naknade za leasing u ugovoru o operativnom leasingu proizlazi da naknada za leasing nema samo funkciju naknade za uporabu stvari, kao što je to slučaj s najamninama u ugovoru o najmu, već ima i funkciju nadoknade investicijskih troškova davatelja leasinga te funkciju nadoknade troškova financiranja davatelja leasinga. Opširnije o metodi izračuna naknade za leasing i funkcijama naknade za leasing u ugovoru o operativnom leasingu vidi u: Tot, I., Operativni leasing, doktorski rad, Pravni fakultet Sveučilišta u Zagrebu, Zagreb, 2016., str. 217. - 222.

3 O pojmu investicijskog rizika (njem. Investitionsrisiko) u poslu leasinga vidi, primjerice, u: Grundmann, W., Leasing und Factoring - Formen, Rechtsgrundlagen, Verträge, Springer Gabler, Wiesbaden, 2013., str. 41.; Kratzer, J. i Kreuzmair, B., Leasing in Theorie und Praxis, Gabler Verlag, Wiesbaden, 2002., str. 122.-123.; Riedler, A., Bestandvertrag, u: Apathy, P. i Riedler, A., Bürgerliches Recht, Band III, Schuldrecht, Besonderer Teil, Springer, Wien New York, 2010., str. 120.; Schimmelschmidt, U., Finanzierungsleasing: eine EDV-gestützte Vorteilhaftigkeitsanalyse, Gabler Verlag, Wiesbaden, 1994., str. 8. 
iz druge naknade ostvarene poduzimanjem nekog drugog pravnog posla $\mathrm{s}$ istim objektom leasinga. Stoga dio ukupnog investicijskog rizika davatelja leasinga u poslu operativnog leasinga predstavlja i rizik unovčenja objekta leasinga koji obuhvaća gospodarske rizike i prilike da se preostali dio nabavne vrijednosti objekta leasinga nadoknadi unovčenjem objekta leasinga po isteku ugovora o operativnom leasingu. ${ }^{4} \mathrm{U}$ pojedinim modelima ugovora o leasingu rizik unovčenja objekta leasinga u potpunosti snosi davatelj leasinga, no u poslovnoj praksi javljaju se i modeli ugovora o leasingu u kojima se rizik unovčenja objekta leasinga ugovornim odredbama ugovora o leasingu prenosi na primatelja leasinga.

U austrijskoj i njemačkoj poslovnoj praksi razvila su se dva modela ugovora o leasingu motornog vozila koja se razlikuju ovisno o tome koja je ugovorna strana ugovora o leasingu nositelj rizika unovčenja ostatka vrijednosti motornog vozila po isteku ugovora o leasingu. $\mathrm{U}$ jednom modelu, koji se u poslovnoj praksi i pravnoj književnosti naziva ugovorom s obračunom kilometraže (njem. KilometerAbrechnungsvertrag), ${ }^{5}$ dio početnih investicijskih troškova koji davatelj leasinga nije

4 O riziku unovčenja objekta leasinga (njem. Verwertungsrisiko) u opisanom smislu pišu, primjerice: Berninghaus, J., Fahrzeugleasing, u: Büschgen, H. E. (ur.), Praxishandbuch Leasing, C. H. Beck'sche Verlagsbuchhandlung, München, 1998., str. 393.-394.; Büschgen, H. E., Die Leasingentscheidung des Leasingnehmers, u: ibid., str. 832.-833.; Engel, J., Handbuch Kraftfahrzeugleasing, Verlag C.H. Beck, München, 2015., str. 227.; Fink, C., Bewertungstheoretische Grundlagen der Leasingfinanzierung - Rechtliche Rahmenbedingungen in Österreich, Springer - Gabler, Wiesbaden, 1997., str. 20.; Krejci, H., Zivilrechtsfragen zum Leasingvertrag, u: Egger, A. i Krejci, H. (ur.), Das Leasinggeschäft - Zivil-, Bilanz- und Steuerrecht, Betriebswirtschaft und Praxis, Wirtschaftsverlag Dr. Anton Orac, Wien, 1987., str. 137.-138.; Martinek, M. i Wimmer-Leonhardt, S., Besonderheiten bei Beendigung eines Kfz-Leasingvertrags und die Verwertung des Leasingfahrzeugs, u: Martinek, M., Stoffels, M. i Wimmer-Leonhardt, S. (ur.), Handbuch des Leasingrechts, Verlag C.H. Beck, München, 2008., str. 546. - 547.

Često se s istovjetnim značenjem u austrijskoj i njemačkoj pravnoj književnosti rabi i pojam rizika ostatka vrijednosti objekta leasinga (njem. Restwertrisiko), pa tako, primjerice, i: Engel, J., loc. cit. u ovoj bilj.; Findeisen, K. - D., Bilanzierung bei wirtschaftlichen Eigentum des Leasinggebers, u: Büschgen, H. E., op. cit. u ovoj bilj., str. 501.; Fischer-Czermak, C., Mobilienleasing - Rechtsnatur, Gewährleistung und Gefahrtragung, Manzsche Verlags- und Universitätsbuchhandlung, Wien, 1995., str. 36.; Kaiser, D. (red.), J. von Staudingers Kommentar zum Bürgerlichen Gesetzbuzch mit Einführungsgesetz und Nebengesetzen - Buch 2 - Recht der Schuldverhältnisse - Leasing (Leasingrecht) - Neubearbeitung 2014 von Markus Stoffels, Sellier - de Gruyter, Berlin, 2014. (dalje u tekstu: Stoffels, M. u: Staudinger), str. 31.; Koch, J., Finanzierungsleasing, u: Krüger, W. i Westermann, H. P. (red.), Münchener Kommentar zum Bürgerlichen Gesetzbuch - Band 3 - Schuldrecht - Besonderer Teil - §§ 433 - 610, Verlag C. H. Beck, München, 2012. (dalje u tekstu: Koch, J. u: MünchKomm III), Rn. 135.; Martinek, M. i Wimmer-Leonhardt, S. u: Martinek et al., loc. cit. u ovoj bilj.; Peters, B. u: Peters, B. i Schmid-Burgk, K., Das Leasinggeschäft, Bank-Verlag Medien, Köln, 2011., str. 91. - 92.; Scharff, U., KFZ-Leasing, u: Beckmann, H. i Scharff, U., Leasingrecht - Rechtsprobleme beim Finanzierungsleasing, Verlag C.H. Beck, München, 2015., str. 360.; Schopper, A. i Skarics, F., Das Leasinggeschäft, u: Apathy, P., Iro, G. i Koziol, H. (ur.), Österreichisches Bankvertragsrecht - Band VII: Leasing, Factoring und Forfaitierung, Verlag Österreich, Wien, 2015., str. 24.-25.; Zahn, H., Pkw-Leasing, u: Graf von Westphalen, F. (ur.), Der Leasingvertrag, Verlag Dr. Otto Schmidt, Köln, 2015., str. 892. - 893.

5 Vidi infra, bilj. 27. 
nadoknadio putem naknade za leasing on nadoknađuje unovčenjem ostatka vrijednosti motornog vozila nakon što mu je motorno vozilo vraćeno po isteku ugovora o leasingu, pri čemu primatelj leasinga nema obvezu plaćanja davatelju leasinga razlike između niže cijene motornog vozila ostvarene unovčenjem i višeg iznosa u vrijeme sklapanja ugovora o leasingu kalkuliranog ostatka vrijednosti motornog vozila koji je ono predvidivo trebalo imati po isteku ugovora o leasingu. U drugom modelu, koji se u poslovnoj praksi i pravnoj književnosti naziva ugovorom s obračunom ostatka vrijednosti (njem. Vertrag mit Restwertabrechnung), ${ }^{6}$ primatelj leasinga se ugovorom o leasingu obvezuje davatelju leasinga osim ugovorene naknade za leasing podmiriti i razliku između niže cijene motornog vozila ostvarene unovčenjem i višeg iznosa kalkuliranog ostatka vrijednosti motornog vozila. U prvom modelu rizik unovčenja motornog vozila je u cijelosti na davatelju leasinga, dok je u drugom modelu taj rizik ugovornim odredbama ugovora o leasingu prenesen na primatelja leasinga.

Među pojavnim oblicima posla operativnog leasinga prema kriteriju vrste objekta leasinga, na hrvatskom tržištu leasinga posao operativnog leasinga motornih vozila najzastupljeniji je pojavni oblik posla operativnog leasinga. ${ }^{7} \mathrm{U}$ hrvatskom pravu prava i obveze sudionika u poslu leasinga dijelom su uređena odredbama Zakona o leasingu. ${ }^{8}$ Među ostalim, odredbama čl. 52. st. 1. i 3. ZL-a propisan je i obavezni sadržaj ugovora o operativnom leasingu, dok je odredbom čl. 52. st. 7. ZL-a povjereno HANFA-i detaljnije pravilnikom propisati sadržaj ugovora o operativnom leasingu, što je i učinjeno Pravilnikom o sadržaju i obliku ugovora o leasingu te metodologiji izračuna efektivne kamatne stope. ${ }^{9}$ Prema odredbi čl. 52. st. 3. t. 2. ZL-a, ugovor o operativnom leasingu obvezno sadrži i odredbu o ostatku vrijednosti objekta leasinga, a taj je pojam definiran odredbom čl. 12. Pravilnika kao "sporazumom utvrđena vrijednost objekta leasinga po isteku ugovorenog trajanja ugovora o operativnom leasingu, a koja utječe na izračun visine mjesečnih obroka”. Odredbama ZL-a, a ni odredbama Pravilnika, nisu uređena prava i obveze ugovornih strana ugovora o operativnom leasingu za slučaj da je iznos cijene ostvarene prodajom objekta leasinga po isteku ugovora o operativnom leasingu niži od iznosa ostatka vrijednosti objekta leasinga. Odgovor na pitanje je li primatelj leasinga obvezan davatelju leasinga naknaditi razliku između tih iznosa, odnosno je li na primatelja leasinga prenesen rizik unovčenja objekta leasinga, u hrvatskom pravu je u domeni slobode ugovaranja ugovornih strana i ovisit će o sadržaju ugovornih odredbi ugovora o operativnom leasingu.

Ugovori o operativnom leasingu motornih vozila uobičajeno se sklapaju uz

$6 \quad$ Vidi infra, bilj. 81.

7 Prema posljednjem objavljenom mjesečnom izvješću Hrvatske agencije za nadzor financijskih usluga (dalje u tekstu: HANFA) dostupnom na dan 1. siječnja 2017. (HANFA, Mjesečni izvještaj - studeni 2016., <http://www.hanfa.hr/getfile/44380/mi\%2012_16.xlsx>, 1. siječnja 2017., tablica 48), ukupno je aktivnih ugovora o operativnom leasingu na hrvatskom tržištu leasinga na dan 30. rujna 2016. bilo 51 168, od čega je aktivnih ugovora o operativnom leasingu osobnih automobila i gospodarskih vozila bilo 49 158, odnosno $96,07 \%$.

8 Zakon o leasingu, NN, br. 141/13. (dalje u tekstu: ZL).

9 HANFA, Pravilnik o sadržaju i obliku ugovora o leasingu te metodologiji izračuna efektivne kamatne stope, NN, br. 66/14. (dalje u tekstu: Pravilnik). 
primjenu općih uvjeta poslovanja davatelja leasinga. Analiza odredaba općih uvjeta poslovanja za ugovore o operativnom leasingu motornih vozila čiji su sastavljači hrvatska leasing društva, ${ }^{10}$ te pojedinih ugovora o operativnom leasingu koji su sklopljeni uz primjenu općih uvjeta poslovanja hrvatskih leasing društava, ${ }^{11}$ pokazuje da se pod nazivom ugovora o operativnom leasingu u hrvatskoj poslovnoj praksi javljaju: (i) ugovori u kojima je rizik unovčenja motornog vozila po redovnom isteku

10 Istraživanjem su obuhvaćeni opći uvjeti poslovanja za ugovore o operativnom leasingu svih šesnaest leasing društava koja se na dan 1. siječnja 2017. aktivno bave poslom operativnog leasinga motornih vozila na hrvatskom tržištu leasinga. Istraživanjem nisu obuhvaćeni opći uvjeti poslovanja četiri leasing društva u likvidaciji te tri leasing društva koja se bave isključivo poslovima leasinga nekretnina i informatičke opreme. Rad se pri navođenju pojedinih odredbi analiziranih općih uvjeta poslovanja poziva samo na tekst onih općih uvjeta poslovanja koji su javno dostupni na mrežnim stranicama hrvatskih leasing društava: ALD Automotive d.o.o., Opći uvjeti ugovora o operativnom leasingu od 16.01.2016., <http:/www.aldautomotive.hr/ Portals/croatia/adam/Content/xmOvRU3M8kOO9etV4_WtTA/Link_Url/GTB\%20ALD\%20 Automotive\%20Cro_2016_01\%20Final.pdf>, 7. siječnja 2017. (dalje u tekstu: OU ALD); BKS - leasing Croatia d.o.o., Opći uvjeti ugovora o operativnom leasingu motornog vozilal pokretnine, 1.9.2016., <http://www.bks-leasing.hr/BKSWebp/BKS/Informationsobjekte/ PDFs/HR_Leasing/AGB/Opci_uvjeti_OPERATIVNI_POKRETNINE.pdf >, 7. siječnja 2017. (dalje u tekstu: OU BKS); Erste \& Steiermärkische $\bar{S}$-Leasing d.o.o., Opći uvjeti uz ugovore o operativnom leasingu broj OL-07000, 11.11.2015., <https://www.ersteleasing.hr/content/ dam/hr/el/ www.ersteleasing.hr/dokumentacija/opci-uvjeti-i-naknade/opci-uvjeti-uz-ugovoreo-operativnom-leasingu.pdf $>$, 7. siječnja 2017. (dalje u tekstu: OU SL); EUROLEASING d.o.o., Opći uvjeti ugovora o operativnom leasingu br. 01/15, studeni 2015., <http:// www.euroleasing.hr/downloads.aspx>, 7. siječnja 2017. (dalje u tekstu: OU EL); HYPO LEASING STEIERMARK d.o.o., Opći uvjeti ugovora o operativnom leasingu pokretnina 10/2011-IV, 1.10.2011., <http://leasing.hypobank.at/hr/pub/document/?id=237\&doc=175620160122-121514-opci_uvjeti_ol_iv.pdf\&typ=pdf $>$, 7. siječnja 2017. (dalje u tekstu: OU HLS); IMPULS-LEASING d.o.o., Opći uvjeti poslovanja društva IMPULS - LEASING d.o.o. za sklapanje ugovora o operativnom leasingu OL $011507,<\mathrm{http} / / \mathrm{www}$.impulsleasing.hr/UserDocsImages/dokumenti/Op\%C4\%87i\%20uvjeti\%20operativni\%20leasing\% 20verzija\%2007.pdf $>$, 7. siječnja 2017. (dalje u tekstu: OU IL); IMPULS - LEASING d.o.o., Opći uvjeti poslovanja društva IMPULS - LEASING d.o.o. za sklapanje ugovora o operativnom leasingu s ugovorenom visinom ostatka vrijednosti RWL 0115 07, <http://www.impuls-leasing. hr/UserDocsImages/dokumenti/ Op\%C4\%87i\%20uvjeti\%20operativni\%20leasing\%20s\%20 ugovorenom\%20visinom\%20ostatka\%20vrijednosti\%20verzija\%2007.pdf>, 7. siječnja 2017. (dalje u tekstu: OU IL-RWL); OTP Leasing d.d., Opći uvjeti ugovora o operativnom leasingu vozila, opreme i drugih pokretnina OL-POK-06, <http://www.otpleasing.hr/User DocsImages/ pdf/Op\%C4\%87i\%20uvjeti\%20ugovora\%20o\%20operativnom\%20leasingu\%20OL-POK-06. pdf $>$, 7. siječanj 2017. (dalje u tekstu: OU OTP); PBZ-LEASING d.o.o., Opći uvjeti PBZL-a za ugovor o operativnom leasingu: v.16.04, 11.4.2016., <http://www.pbz-leasing.hr/media/1077/ op_i_uvjeti_pbzl-a_za_ugovor_o__operativnom_leasingu_v_1604_vozilo_plovilo_ oprema.pdf`, 7. siječnja 2017. (dalje u tekstu: OU PBZ); Raiffeisen Leasing d.o.o., Opći uvjeta ugovora o operativnom leasingu 02_16, 15.2.2016., <http://www.rl-hr.hr/UserDocsImages/ OP\%C4\%86I\%20UVJETI\%20-\%20OPERATIVNI\%20LEASING.pdf>， 7. siječnja 2017. (dalje u tekstu: OU RL); SG Leasing d.o.o., Opći uvjeti operativnog leasinga, 28.7.2016., $<$ http://www.sgleasing.hr/wp-content/uploads/2016/12/Opci-uvjeti-OL-2016-07-28-v2.pdf>, 7. siječnja 2017. (dalje u tekstu: OU SG).

11 U istraživanju je analizirano osamdeset i devet ugovora o operativnom leasingu sklopljenih uz primjenu općih uvjeta poslovanja različitih hrvatskih leasing društava. 
ugovora i u slučaju prijevremenog prestanka ugovora na davatelju leasinga; (ii) ugovori u kojima je rizik unovčenja motornog vozila po redovnom isteku ugovora i u slučaju prijevremenog prestanka ugovora na primatelju leasinga; te (iii) ugovori s promjenom metode konačnog obračuna $u$ kojima je davatelj leasinga nositelj rizika unovčenja motornog vozila samo u slučaju redovnog isteka ugovora, dok je u slučaju prijevremenog prestanka ugovora taj rizik na primatelju leasinga.

Predmet ovog rada je analiza prava i obveza ugovornih strana ugovora o operativnom leasingu motornog vozila u vezi s vraćanjem i unovčenjem motornog vozila po isteku ugovora o operativnom leasingu u različitim modelima ugovora o operativnom leasingu motornih vozila koji se javljaju u hrvatskoj poslovnoj praksi. Obilježja tih modela ugovora o operativnom leasingu motornog vozila uspoređuju se s obilježjima dva najčešća modela ugovora o leasingu motornog vozila iz austrijske i njemačke poslovne prakse: ugovorom s obračunom kilometraže i ugovorom $s$ obračunom ostatka vrijednosti. Cilj te usporedbe je utvrditi mogu li se pojedina rješenja razvijena u austrijskoj i njemačkoj sudskoj praksi te pravnoj književnosti u vezi s tim modelima ugovora o leasingu opravdano recipirati i u kontekstu hrvatskoga prava. ${ }^{12}$ Primjenom dogmatsko-normativne i poredbenopravne metode u ovom radu smjera se: (i) pružiti odgovore na teorijska pitanja u vezi s ugovorima o operativnom leasingu motornih vozila, kao što je to, primjerice, pitanje funkcija pojedinih ugovorenih naknada tipičnih za taj pravni posao, a kojim pitanjima se hrvatska pravna književnost nije prethodno bavila, ${ }^{13}$ (ii) pružiti odgovore na praktična pitanja koja se u poslovnoj praksi postavljaju u vezi s prestankom ugovora o operativnom leasingu i unovčenjem

12 Za razliku od hrvatskoga prava, obveznopravni aspekti ugovora o leasingu u austrijskom i njemačkom pravu nisu uređeni zakonom. "Pravo leasinga" (njem. Leasingrecht) razvija se u tim pravnim poredcima u sudskoj praksi, zbog čega se ono karakterizira i kao "ad hoc stvoreno sudsko pravo" (primjerice, u: Gonzales del Campo, F., Neue Vertragsformen als Rechtstransfer? Zum Topos der angloamerikanischen Provenienz des Leasing-Rechts, Rechtsgeschichte: Zeitschrift des Max-Planck-Instituts für Europäische Rechtsgeschichte, vol. 7, 7/2005, str. 51.). U primjeni poredbenopravne metode u ovom radu austrijsko i njemačko pravo odabrano je zbog: (i) oslonjenosti hrvatskog obveznog prava na pravne poretke germanskog pravnog kruga, te (ii) okolnosti da su osnivači većine hrvatskih leasing društava austrijska i njemačka trgovačka društva.

13 U razdoblju nakon što je usvojen Zakon o leasingu (NN, br. 135/06.) kojim su pojedini obveznopravni aspekti posla leasinga bili prvi put uređeni u hrvatskom pravu, objavljeno je više znanstvenih radova koji u svom fokusu imaju novo zakonsko uređenje ugovora o leasingu u hrvatskom pravu. Ti se radovi, međutim, ne bave analizom konkretnih ugovornih odredaba ugovora o operativnom leasingu u hrvatskoj poslovnoj praksi, a analiza tih odredaba nije zastupljena ni u starijoj hrvatskoj pravnoj književnosti. U novijoj znanstvenoj literaturi posebno se ističu radovi: Josipović, T., Financial leasing in Croatia, Uniform Law Review, vol. 16, 1-2/2011., str. 271. - 289.); Keglević, A., Ugovor o leasingu - novi imenovani ugovor hrvatskog prava, u: Gliha, I., Josipović, T., Belaj, V., Baretić, M., Nikšić, S., Ernst, H., Keglević, A. i Matanovac, R. (ur.), Liber amicorum Nikola Gavella - Građansko pravo u razvoju, Pravni fakultet Sveučilišta u Zagrebu, Zagreb, 2007., str. 607. - 657.; Parać, Z., Zakon o leasingu (ili što je to pjesnik stvarno htio reći), Pravo u gospodarstvu, vol. 46, 4/2007., str. 147. - 184.; Pešutić, A., Ugovor o leasingu, u: Slakoper, Z. (ur.), Bankovni i financijski ugovori, Pravni fakultet Sveučilišta u Rijeci, Rijeka, 2007., str. 1007. - 1029. 
objekta leasinga nakon prestanka tog ugovora ${ }^{14}$ te time (iii) pružiti hrvatskoj sudskoj praksi smjernice kojima bi se ona mogla služiti pri rješavanju spornih pitanja koja se javljaju u vezi s pravima i obvezama ugovornih strana ugovora o operativnom leasingu motornog vozila, posebno onih koja se tiču ocjene valjanosti ugovornih odredaba sadržanih u općim uvjetima poslovanja za ugovore o operativnom leasingu. ${ }^{15}$

Rad je strukturiran u pet poglavlja. Iza prvog uvodnog poglavlja slijede tri poglavlja u kojima se analiziraju različiti ugovorni modeli ugovora o operativnom leasingu motornih vozila iz hrvatske poslovne prakse u poredbi s njima usporedivim modelima ugovora o leasingu motornih vozila iz austrijske i njemačke poslovne prakse. U drugom poglavlju analizira se ugovorni model u kojemu je davatelj leasinga u svakom slučaju nositelj rizika unovčenja objekta leasinga, a koji je usporediv s ugovorom o leasingu s obračunom kilometraže iz austrijske i njemačke poslovne prakse. U trećem poglavlju analizira se ugovorni model u kojemu je primatelj leasinga u svakom slučaju nositelj rizika unovčenja objekta leasinga, a koji je usporediv s ugovorom o leasingu $\mathrm{s}$ obračunom ostatka vrijednosti iz austrijske i njemačke poslovne prakse. U četvrtom poglavlju analizira se ugovorni model s promjenom metode konačnog obračuna u kojemu prijenos rizika unovčenja objekta leasinga ovisi o tome je li ugovor o operativnom leasingu prestao redovno istekom vremena na koje je sklopljen ili je prestao prijevremeno prije isteka ugovorenog trajanja ugovora o operativnom leasingu, a koji predstavlja kombinaciju različitih obilježja koja su u austrijskoj i njemačkoj poslovnoj praksi karakteristična za ugovor s obračunom kilometraže i za ugovor s obračunom ostatka vrijednosti. Temeljni rezultati provedenog istraživanja rezimiraju se u petom, zaključnom poglavlju rada.

\section{UGOVOR O OPERATIVNOM LEASINGU U KOJEMU JE DAVATELJ LEASINGA NOSITELJ RIZIKA UNOVČENJA MOTORNOG VOZILA}

Opći uvjeti poslovanja za ugovore o operativnom leasingu jednoga hrvatskog leasing društva sadržavaju izričite odredbe iz kojih nedvojbeno proizlazi da primatelj leasinga nema nikakvih ugovornih obveza prema davatelju leasinga koje bi se odnosile na naknadu razlike između niže cijene motornog vozila ostvarene unovčenjem po

14 S tim u vezi korisno je istaknuti da se najveći broj prigovora primatelja leasinga na postupanje leasing društava koje zaprima HANFA i povodom kojih poduzima odgovarajuće mjere u okviru svojih nadzornih ovlasti na tržištu leasinga odnosi upravo na obračun potraživanja, vraćanje i prodaju objekta leasinga nakon prijevremenog prestanka ugovora o leasingu (prema: HANFA, Godišnje izvješće 2015., <http://www.hanfa.hr/getfile/44255/Godisnje\%20izvjesce\%202015_ web.pdf>, 7. siječnja 2017., str. 141.).

15 U tri u radu analizirane presude iz hrvatske sudske prakse, sudovi su se, među ostalim, bavili i pitanjem ništetnosti odredaba općih uvjeta poslovanja za ugovore o operativnom leasingu iz kojih je proizlazila obveza primatelja leasinga naknaditi davatelju leasinga i iznos ostatka vrijednosti objekta leasinga: Općinski sud u Samoboru, Povrv-1691/12 od 6. lipnja 2014. (neobjavljena); Trgovački sud u Zagrebu, P-481/2013 od 7. srpnja 2014. (neobjavljena); Županijski sud u Bjelovaru, Gž-2540/11-3 od 1. ožujka 2012., dostupno na: Portal IUS-INFO, $<$ http://www.iusinfo.hr/>, 7. siječnja 2017. 
redovnom isteku ugovora o operativnom leasingu i višeg iznosa unaprijed kalkuliranog ostatka vrijednosti motornog vozila.

U tim općim uvjetima poslovanja ističe se da primatelj leasinga u odnosu na objekt leasinga "nema nikakvu obvezu kod pada njegove vrijednosti kroz razdoblje Ugovora o operativnom leasingu niti tražbinu kod njegove veće vrijednosti", ${ }^{16}$ te da je davatelj leasinga "potpuno slobodan" s objektom leasinga "nakon prestanka Ugovora raspolagati na način dopušten leasing društvu, osobito prodati odnosni objekt leasinga, zasnovati novi pravni posao leasinga ili pravni posao zakupa odnosno najma odnosnog objekta leasinga", ${ }_{17}$ pri čemu "financijski učinak takvog daljnjeg postupanja Davatelja leasinga nema učinak na Konačni obračun ugovora". ${ }^{18}$ Ugovorne odredbe tih općih uvjeta poslovanja koje se odnose na konačni obračun tražbina davatelja leasinga po isteku ugovorenog razdoblja na koje je ugovor o operativnom leasingu sklopljen ne sadrže među parametrima relevantnim za obračun ni iznos ostvaren unovčenjem objekta leasinga niti iznos kalkuliranog ostatka vrijednosti motornog vozila. ${ }^{19}$ Također, ti iznosi nisu spomenuti ni među relevantnim parametrima za konačni obračun $u$ slučaju prijevremenog prestanka ugovora o operativnom leasingu..$^{20}$

Prestane li ugovor o operativnom leasingu prijevremeno, odnosno prije isteka ugovorenog trajanja ugovora o operativnom leasingu, kao što je to, primjerice, u slučaju jednostranog raskida ugovora zbog zakašnjenja primatelja leasinga $s$ plaćanjem mjesečnih obroka naknade za leasing, primatelj leasinga obvezuje se odredbama tih općih uvjeta poslovanja platiti posebnu "jednokratnu naknadu za prijevremeni prestanak Ugovora o operativnom leasingu". ${ }^{21}$ Ta jednokratna naknada obračunava se kao umnožak ugovorenog postotka od nabavne cijene objekta leasinga i broja preostalih mjeseci do isteka ugovorenog vremena na koje je ugovor o operativnom leasingu bio sklopljen. ${ }^{22}$ Iz ugovorene metode obračuna te jednokratne naknade može se zaključiti: (i) da je riječ o paušaliziranom zahtjevu za naknadu štete zbog neispunjenja ugovora o operativnom leasingu, ${ }^{23}$ te (ii) da iznos ostvaren unovčenjem objekta leasinga nije relevantan ni za izračun jednokratne naknade za prijevremeni prestanak ugovora. Potonje potvrđuje i ugovorna odredba prema kojoj obračun te naknade ne ovisi o postupanju davatelja leasinga s objektom leasinga

16 Odredba čl. 23.3. OU ALD.

17 Odredba čl. 23.4. OU ALD.

18 Ibid.

19 Odredbe čl. 23.1. - 23.5. i 23.13. OU ALD.

20 Odredbe čl. 23.1. - 23.6. OU ALD.

21 Odredba čl. 23.7. OU ALD.

22 Prema odredbi čl. 23.8. OU ALD-a, jednokratna naknada za prijevremeni prestanak ugovora obračunava se kao umnožak (i) iznosa koji odgovara $2 \%$ nabavne cijene objekta leasinga (ako je ugovor o operativnom leasingu bio sklopljen na vrijeme kraće od dvadeset i četiri mjeseca) ili $1 \%$ nabavne cijene objekta leasinga (ako je ugovor o operativnom leasingu bio sklopljen na vrijeme duže od dvadeset i četiri mjeseca) i (ii) preostalog broja mjeseci do isteka ugovorenog vremena trajanja ugovora.

23 Klauzulama s paušaliziranim zahtjevima za naknadom štete određuje se visina štete, a da se pritom ne stvara novi pravni temelj te štete, a o njima iscrpno vidi u: Miladin, P., Razgraničenje između klauzula o ugovornoj kazni i klauzula s paušaliziranim zahtjevima za naknadom štete, Zbornik Pravnog fakulteta u Zagrebu, vol. 52., 2/2002., str. 406. - 415. 
nakon prijevremenog prestanka ugovora te prema kojoj to "daljnje postupanje nema učinak na obračun odnosne naknade niti je temelj za stjecanje prava odnosno nastanak obveza Primatelja leasinga". ${ }^{24}$

Iz analize ugovornih odredaba ovih općih uvjeta poslovanja za ugovore o operativnom leasingu, pojedinačno i u njihovoj ukupnosti, proizlazi da u ugovorima o operativnom leasingu sklopljenim uz primjenu tih općih uvjeta poslovanja rizik unovčenja objekta leasinga isključivo snosi davatelj leasinga.

Isti opći uvjeti poslovanja za ugovore o operativnom leasingu sadrže i odredbe kojima je ugovoreno: (i) da je jedan od parametara za izračun naknade za leasing i ugovorena kilometraža motornog vozila, tj. ugovorom određeni maksimalni broj kilometara kojeg je motornim vozilom dopušteno dostignuti tijekom ugovorenog trajanja ugovora o operativnom leasingu; ${ }^{25}$ (ii) da se primatelj leasinga obvezuje vratiti motorno vozilo davatelju leasinga po isteku ugovorenog trajanja ugovora o operativnom leasingu u stanju koje odgovara, među ostalim, i ugovorenoj kilometraži motornog vozila; ${ }^{26}$ (iii) da se primatelj leasinga obvezuje platiti davatelju leasinga posebnu naknadu za prekoračenje ugovorene kilometraže ${ }^{27}$ te (iv) da se davatelj leasinga obvezuje platiti primatelju leasinga posebnu naknadu u slučaju nedostizanja ugovorene kilometraže. ${ }^{28}$

Ugovaranje ograničenja ukupne kilometraže i posebnih naknada za prekoračenje i nedostizanje ugovorene kilometraže motornog vozila te okolnost da je davatelj leasinga nositelj rizika unovčenja motornog vozila, ključna su obilježja modela ugovora o leasingu motornog vozila kojeg se u austrijskoj i njemačkoj poslovnoj praksi naziva ugovorom s obračunom kilometraže (njem. Kilometer-Abrechnungsvertrag). ${ }^{29}$ Prema tim ključnim obilježjima, opisani ugovorni model ugovora o operativnom leasingu motornog vozila iz hrvatske poslovne prakse usporediv je s ugovorom s obračunom kilometraže. Stoga se u nastavku analizira tretman tog ugovora u austrijskom i njemačkom pravu i ispituje mogu li se rješenja razvijena u austrijskoj i njemačkoj sudskoj praksi i pravnoj književnosti primijeniti u kontekstu pozitivnoga hrvatskog

24 Odredba čl. 23.12. OU ALD.

25 Odredbe čl. 11.3. i 11.4. OU ALD.

26 Odredba čl. 24.3. OU ALD.

27 Odredba čl. 24.2. OU ALD.

28 Ibid.

29 Ta karakteristična obilježja ugovora s obračunom kilometraže u austrijskoj i pravnoj književnosti ističu: Berninghaus, J. u: Büschgen, H. E., op. cit. u bilj. 3, str. 396.; Engel, J., op. cit. u bilj. 3, str. 73.; Godefroid, C., Kraftfahrzeugleasingverträge mit Kilometerabrechnung und $\S 506$ BGB, Straßenverkehrsrecht - die Zeitschrift für die Praxis des Verkehrsjuristen, vol. 13., 5/2013., str. 163.; Grundmann, W., op. cit. u bilj. 2, str. 104.; Kratzer, J. i Kreuzmair, B., op. cit. u bilj. 2, str. 73.; Martinek, M., Erscheinungsformen des Leasings, u: Martinek, M. et al., op. cit. u bilj. 3, str. 31.; Martinek, M. i Wimmer-Leonhardt, S. u: Martinek, M. et al., loc. cit. u bilj. 3; Oechsler, J., Schuldrecht - Besonderer Teil - Vertragsrecht, Verlag Franz Vahlen, München, 2003., str. 282.; Peters, B. u: Peters, B. i Schmid-Burgk, K., op. cit. u bilj. 3, str. 92.; Schopper, A. i Skarics, F. u: Apathy, P. et al., op. cit. u bilj. 3, str. 33. - 34.; Scharff, U. u: Beckmann, H. i Scharff, U., op. cit. u bilj. 3, str. 359. - 360.; Stoffels, M. u: Staudinger, op. cit. u bilj. 3, str. 30. - 31.; Zahn, H. u: Graf von Westphalen, F., op. cit. u bilj. 3, str. 892. Rjeđe se za ovaj model ugovora rabi i naziv Kilometer-Leasingvertrag, pa tako, primjerice, u: Scharff, U. u: Beckmann, H. i Scharff, U., op. cit. u bilj. 3, str. 359. 
prava na opisani ugovorni model iz hrvatske poslovne prakse.

\subsection{Ugovoreno ograničenje ukupne kilometraže motornog vozila}

Za ugovor s obračunom kilometraže iz austrijske i njemačke poslovne prakse karakteristično je da davatelj leasinga i primatelj leasinga ugovaraju ograničenje kilometraže (njem. Kilometerbegrenzung) motornog vozila koje je objekt leasinga. Ukupna kilometraža motornog vozila (njem. Gesamtfahrleistung) određuje se sporazumno kao maksimalni broj kilometara kojega je motornim vozilom dopušteno dostignuti tijekom cjelokupnog ugovorenog trajanja ugovora o leasingu. ${ }^{30}$ Odredba o ograničenju ukupne kilometraže na određeni broj kilometara nije opća odredba koja bi bila sadržana u općim uvjetima poslovanja ili tarifi nekog leasing društva i koja bi se imala primijeniti na svaki ugovor o leasingu koji se sklapa s tim leasing društvom. Riječ je o pojedinačno ugovorenom sastojku ugovora koji se zajedno s drugim sastojcima o kojima su ugovorne strane pojedinačno pregovarale unosi u samu ispravu ugovora o leasingu u kojoj je sadržana i odredba kojom se opći uvjeti poslovanja i tarifa leasing društva inkorporiraju u ugovor. Ograničenje ukupne kilometraže motornog vozila redovito se određuje na temelju onoga što je primatelj leasinga priopćio davatelju leasinga prije sklapanja ugovora o svojim potrebama u vezi s uporabom motornog vozila. ${ }^{31} \mathrm{~S}$ istovjetnim značenjem i na istovjetan način kao i u austrijskoj i njemačkoj poslovnoj praksi, ograničenje ukupne kilometraže motornog vozila redovito se ugovara i u supra opisanom modelu ugovora o operativnom leasingu motornog vozila iz hrvatske poslovne prakse. ${ }^{32}$

Primatelj leasinga obvezuje se vratiti motorno vozilo po isteku ugovora $\mathrm{u}$ stanju koje odgovara ugovorenoj ukupnoj kilometraži motornog vozila. ${ }^{33}$ Po isteku ugovora i vraćanju motornog vozila davatelju leasinga stvarno prijeđena kilometraža utvrđuje se pregledom vozila i unosi u obrazac potvrde o vraćanju vozila (njem. Rückgabeprotokoll). ${ }^{34}$ Odgovara li stvarno prijeđena kilometraža ugovorenoj ukupnoj

30 Usp.: Berninghaus, J. u: Büschgen, H. E., op. cit. u bilj. 3, str. 396.; Engel, J., op. cit. u bilj. 3, str. 73.; Koch, J. u: MünchKomm III, loc. cit. u bilj. 3; Martinek, M. u: Martinek, M. et al., loc. cit. u bilj. 28; Peters, B. u: Peters, B. i Schmid-Burgk, K., op. cit. u bilj. 3, str. 92.; Schopper, A. i Skarics, F. u: Apathy, P. et al., op. cit. u bilj. 3, str. 33.; Stoffels, M. u: Staudinger, op. cit. u bilj. 3, str. 29.

31 Engel, J., op. cit. u bilj. 3, str. 73.

32 Analiza pojedinih ugovora o operativnom leasingu sklopljenih uz primjenu OU ALD-a pokazuje da se ograničenje ukupne kilometraže motornog vozila redovito odnosi na cjelokupno ugovoreno trajanje ugovora. Odredbe OU ALD-a ne sadrže opće ograničenje ukupne kilometraže motornog vozila koje bi se imalo primijeniti na svaki ugovor o operativnom leasingu sklopljen uz primjenu OU ALD. Prema odredbi čl. 11.4. OU ALD-a, izračun naknade za leasing ovisi i o "kilometraži koju kroz vrijeme trajanja leasinga Primatelj leasinga namjerava prijeći vozilom", a koju "Primatelj leasinga priopćava Davatelju leasinga pri izradi ponude za financiranje putem leasinga".

33 Usp.: Berninghaus, J. u: Büschgen, H. E., op. cit. u bilj. 3, str. 397.; Engel, J., op. cit. u bilj. 3, str. 211.; Stoffels, M. u: Staudinger, op. cit. u bilj. 3, str. 29.

34 O potvrdi o vraćanju motornog vozila vidi, primjerice, u: Engel, J., op. cit. u bilj. 3, str. 206. 207. Redovito je riječ o obrascu leasing društva kojim se utvrđuje da je vozilo vraćeno davatelju leasinga i stanje u kojem je ono vraćeno davatelju leasinga, a koji potpisuju davatelj leasinga 
kilometraži, primatelj leasinga ispunio je svoju obvezu vraćanja motornog vozila u ugovorenom stanju, za što je relevantan i okvir dopuštenih odstupanja (njem. Toleranzgrenze) od ugovorene ukupne kilometraže, uobičajeno ugovoren odredbama općih uvjeta poslovanja. U austrijskoj i njemačkoj poslovnoj praksi, uobičajeno se kao prihvatljivo odstupanje od ugovorene ukupne kilometraže ugovara odstupanje do $2500 \mathrm{~km},{ }^{35}$ a to je i okvir dopuštenih odstupanja koji se ugovara i u analiziranom modelu ugovora o operativnom leasingu motornih vozila iz hrvatske poslovne prakse. $^{36}$

Za slučaj prekoračenja ugovorenog ograničenja ukupne kilometraže motornog vozila redovito se ugovara obveza primatelja leasinga platiti davatelju leasinga posebnu naknadu za prekoračenje kilometraže (njem. Mehrkilometerausgleich; Ausgleich der Mehrfahrleistung). ${ }^{37}$ Posebna naknada za prekoračenje kilometraže obračunava se uobičajeno kao umnožak broja prekoračenih kilometara i iznosa naknade po jednom prekoračenom kilometru, ${ }^{38}$ a iznos naknade po prekoračenom kilometru unosi se redovito u samu ispravu ugovora o leasingu zajedno s drugim sastojcima o kojima su ugovorne strane pojedinačno pregovarale. ${ }^{39} \mathrm{~S}$ istovjetnim obilježjima se posebna naknada za prekoračenje kilometraže ugovara i u analiziranom modelu ugovora o operativnom leasingu iz hrvatske poslovne prakse. ${ }^{40}$

Za slučaj nedostizanja ugovorenog ograničenja ukupne kilometraže motornog vozila redovito se ugovara obveza davatelja leasinga platiti primatelju leasingu posebnu naknadu za nedostizanje ukupne kilometraže (njem. Minderkilometerausgleich;

i primatelj leasinga. Takav obrazac uobičajen je i u hrvatskoj poslovnoj praksi gdje se naziva potvrdom o vraćanju, protokolom o preuzimanju, potvrdom o predaji i sl. Za primjer takvog obrasca, vidi: Porsche leasing d.o.o., Potvrda o predaji vozila, $<\mathrm{http} / /$ www.porscheleasing. com.hr/media/Kwc_Basic_DownloadTag_Component/285-10417-2651-10420-linkTag-child/ default/12aaad1c/1477652764/pl_potvrda_predaja_vozila_20_10_2016.pdf>, 7. siječnja 2017. Odredbe o tomu da će pri vraćanju vozila davatelj leasinga $\bar{i}$ primatelj leasinga u pisanom obliku utvrditi vraćanje vozila i njegovo stanje redovito su sadržane i u općim uvjetima poslovanja za ugovore o operativnom leasingu, pa tako, primjerice, i u: čl. 24.3. OU ALD.

35 Usp.: Berninghaus, J. u: Büschgen, H. E., op. cit. u bilj. 3, str. 396.; Engel, J., op. cit. u bilj. 3, str. 74.; Kratzer, J. i Kreuzmair, B., op. cit. u bilj. 2, str. 74.; Martinek, M. u: Martinek, M. et al., loc. cit. u bilj. 28; Martinek, M. i Wimmer-Leonhardt, S., Bedeutung und Erscheinungsformen des Kfz-Leasing, u: Martinek, M. et al., op. cit. u bilj. 3, str. 531.; Schopper, A. i Skarics, F. u: Apathy, P. et al., op. cit. u bilj. 3, str. 34.; Stoffels, M. u: Staudinger, op. cit. u bilj. 3, str. 30.

36 Prema odredbi čl. 24.2. OU ALD-a, "prekoračenje ili nedostizanje ugovorene kilometraže do $2.500 \mathrm{~km}$ neće se uzimati u obzir".

37 Usp.: Berninghaus, J. u: Büschgen, H. E., op. cit. u bilj. 3, str. 396.; Engel, J., op. cit. u bilj. 3, str. 74.; Martinek, M. u: Martinek, M. et al., loc. cit. u bilj. 28; Martinek, M. i WimmerLeonhardt, S. u: Martinek, M. et al., loc. cit. u bilj. 34; Schopper, A. i Skarics, F. u: Apathy, P. et al., op. cit. u bilj. 3, str. 34.; Stoffels, M. u: Staudinger, op. cit. u bilj. 3, str. 30.

38 Usp.: Engel, J., op. cit. u bilj. 3, str. 74.; Scharff, U. u: Beckmann, H. i Scharff, U., op. cit. u bilj. 3, str. 359.

39 Usp.: Engel, J., op. cit. u bilj. 3, str. 261.

40 Prema odredbi čl. 24.2. OU ALD-a, obračun naknade za prekoračenje kilometraže izvršit će se "u skladu sa stopama navedenim u Ugovoru o operativnom leasingu". Analiza pojedinih ugovora o operativnom leasingu sklopljenih uz primjenu OU ALD-a pokazuje da se ugovoreni iznos naknade po jednom kilometru i metoda obračuna naknade za prekoračenje kilometraže redovito navode na prednjoj strani ugovora o operativnom leasingu. 
Ausgleich der Minderfahrleistung).$^{41}$ I ona se uobičajeno obračunava kao umnožak broja manje prijeđenih kilometara u odnosu na ugovoreno ograničenje ukupne kilometraže i iznosa naknade po jednom manje prijeđenom kilometru koji se također unosi $\mathrm{u}$ ispravu ugovora o leasingu. ${ }^{42}$ Obveza davatelja leasinga platiti primatelju leasinga posebnu naknadu za nedostizanje ukupne kilometraže karakteristična je i za analizirani model ugovora o operativnom leasingu iz hrvatske poslovne prakse. ${ }^{43}$

Redovito se naknada po jednom prekoračenom kilometru ugovara u višem iznosu negoli naknada po jednom manje prijeđenom kilometru u odnosu na ugovoreno ograničenje ukupne kilometraže motornog vozila. ${ }^{44}$ Redovito se ugovara i gornja granica ukupnog iznosa naknade za nedostizanje ukupne kilometraže, odnosno maksimalan broj manje prijeđenih kilometara koji će se uzeti u obzir pri obračunu te naknade ${ }^{45}$ To je karakteristično i za analizirani model ugovora o operativnom leasingu iz hrvatske poslovne prakse ${ }^{46}$ Ugovaranje različitih visina iznosa naknade za prekoračenje i naknade za nedostizanje ukupne kilometraže te ograničenja ukupnog iznosa naknade za nedostizanje ukupne kilometraže prikladno je uzme li se u obzir da se obračun naknade za leasing temelji na ograničenju ukupne kilometraže motornog vozila i da se ograničenje ukupne kilometraže određuje na temelju procjene primatelja leasinga o ukupnom broju kilometara koji on predviđa prijeći tijekom ugovorenog razdoblja. Stoga je opravdano da davatelja leasinga ne terete izdatci koji bi bili posljedica nerealistične procjene primatelja leasinga. ${ }^{47}$

Posebno je pitanje bi li potpuno isključenje prava primatelja leasinga na naknadu za nedostizanje ukupne kilometraže dovodilo do značajne neravnoteže između ugovornih strana. U jednoj odluci iz austrijske sudske prakse, austrijski Vrhovni sud (Oberster Gerichtshof; dalje u tekstu: OGH) utvrdio je ništetnost ugovorne odredbe sadržane u općim uvjetima poslovanja davatelja leasinga kojom je izričito isključena bilo koja obveza davatelja leasinga za slučaj nedostizanja ugovorene ukupne kilometraže primatelja leasinga, držeći da je takvom ugovornom odredbom narušeno načelo ravnopravnosti na štetu primatelja leasinga koji se drugom ugovornom

41 Usp.: Berninghaus, J. u: Büschgen, H. E., op. cit. u bilj. 3, str. 396.; Engel, J., op. cit. u bilj. 3, str. 74.; Martinek, M. u: Martinek, M. et al., loc. cit. u bilj. 28; Martinek, M. i WimmerLeonhardt, S. u: Martinek, M. et al., loc. cit. u bilj. 34; Schopper, A. i Skarics, F. u: Apathy, P. et al., op. cit. u bilj. 3, str. 34.; Stoffels, M. u: Staudinger, op. cit. u bilj. 3, str. 30.

42 Usp.: Engel, J., op. cit. u bilj. 3, str. 261.; Scharff, U. u: Beckmann, H. i Scharff, U., op. cit. u bilj. 3, str. 359 .

43 Prema odredbi čl. 24.2. OU ALD-a, obračun naknade za nedostizanje kilometraže izvršit će se "u skladu sa stopama navedenim u Ugovoru o operativnom leasingu".

44 Usp.: Engel, J., op. cit. u bilj. 3, str. 282.; Goldkamp, T. i Reimer, N., Die leasingtypischen Ausgleichsansprüche bei Fahrzeugrückgabe im Rahmen eines Leasingvertrags, Juris - die Monatszeitschrift, vol. 1, 8-9/2014, str. 323.; Honal, M., Loss Given Default von MobilienLeasingverträgen, Gabler Verlag, Wiesbaden, 2009., str. 18.

45 Martinek, M. i Wimmer-Leonhardt, S. u: Martinek, M. et al., loc. cit. u bilj. 34.

46 Prema odredbi čl. 24.2. OU ALD-a, manje prijeđeni kilometri u odnosu na ugovoreno ograničenje ukupne kilometraže "uračunat će se do najviše 10.000 km", a analiza pojedinih ugovora o operativnom leasingu sklopljenih uz primjenu OU ALD-a pokazuje da se naknada po jednom manje prijeđenom kilometru redovito ugovara u nižem iznosu od naknade po jednom prekoračenom kilometru.

47 Usp.: Engel, J., op. cit. u bilj. 3, str. 283. 
odredbom bio obvezao davatelju leasinga platiti naknadu za slučaj prekoračenja ugovorene ukupne kilometraže. ${ }^{48} \mathrm{OGH}$ se u toj odluci primarno fokusirao na pitanje formalne ravnopravnosti ugovornih strana ustanovljujući da nije iznašao stvarno opravdanje za takav različiti tretman ugovornih strana, ${ }^{49}$ no nije analizirao je li ugovorna odredba prema kojoj primatelj leasinga nema pravo na naknadu za nedostizanje ukupne kilometraže, takva da je zbog nje cjelokupni pravni položaj davatelja leasinga povoljniji od pravnog položaja primatelja leasinga. Okolnost da u slučaju nedostizanja ukupne kilometraže davatelj leasinga ne bi imao obvezu platiti primatelju leasinga naknadu za manje prijeđenu kilometražu ne bi se mogla sama po sebi uzeti takvom da onemogućava primatelju leasinga ostvarenje svrhe zbog koje je on sklopio ugovor o operativnom leasingu, o čemu bi hrvatska sudska praksa u usporedivom slučaju morala voditi računa. ${ }^{50}$

Polazeći od toga da je ugovorno ograničenje ukupne kilometraže motornog vozila jedan od elemenata na temelju kojih se određuje naknada za leasing u ugovoru s obračunom kilometraže te od toga da naknada za leasing ima i funkciju nadoknade investicijskih troškova davatelja leasinga, njemačka sudska praksa te pravna književnost drže da i naknada za prekoračenje ukupne kilometraže ima funkciju nadoknade investicijskih troškova davatelja leasinga, slijedom čega zahtjev za plaćanjem te naknade nije zahtjev za naknadom štete, već zahtjev za ispunjenjem primarne ugovorne obveze (njem. Erfüllungsanspruch) ${ }^{51}$ Kako se u analiziranom modelu ugovora o operativnom leasingu iz hrvatske poslovne prakse ograničenje ukupne kilometraže ugovara na istovjetan način i s istovjetnim obilježjima kao i austrijskoj i njemačkoj poslovnoj praksi, stajalište o pravnoj prirodi zahtjeva za plaćanjem naknade za prekoračenje ukupne kilometraže prihvatljivo je i u kontekstu hrvatskoga prava. Iz odredbe čl. 62. st. 1. ZL-a proizlazi obveza primatelja leasinga

$48 \mathrm{OGH}, 7 \mathrm{Ob} 230 / 08 \mathrm{~m}$ od 13. svibnja 2009., dostupno na: Bundeskanzleramt Rechtsinformationssystem, <https://www.ris.bka.gv.at/> (dalje u tekstu: RIS), 8. siječnja 2017.

49 Ibid., str. 28.

50 Formalna neravnopravnost koja postoji ako ugovorne strane nemaju ista prava u usporedivoj situaciji ne znači sama po sebi da interesi ugovornih strana nisu uzeti u obzir u jednakom opsegu zbog čega bi među ugovornim stranama postojala materijalna neravnopravnost koja je relevantna u kontekstu utvrđivanja ništetnosti odredaba općih uvjeta ugovora prema odredbama čl. 296. Zakona o obveznim odnosima (NN, br. 35/05., 41/08., 125/11. i 78/15.; dalje u tekstu: ZOO). Iscrpno o tome vidi u: Baretić, M. i Markovinović, H., Nepoštene ugovorne odredbe opće i posebna uređenja, u: Barbić, J. i Giunio, M. (ur.), Zbornik 50. jubilarnog susreta pravnika Opatija 2012., Hrvatski savez udruga pravnika u gospodarstvu, Zagreb, 2012., str. 94. - 97.

51 Iz sudske prakse njemačkog Saveznog vrhovnog suda (Bundesgerichtshof; dalje u tekstu: BGH) vidi, primjerice, odluke: BGH, VIII ZR 22/12 od 14. studenog 2012., dostupno na: openJur - die freie juristische Datenbank, < https://openjur.de/> (dalje u tekstu: openJur), 8. siječnja 2017., $\S \S 27$. - 28.; BGH, VIII ZR 367/03 od 14. srpnja 2004., dostupno na: openJur, 8. siječnja 2017., $\S 27$. Također, u sudskoj praksi viših zemaljskih sudova (Oberlandesgerichtshof; dalje u tekstu: OLG), OLG u Düsseldorfu je zauzeo stajalište da naknada za prekoračenje ukupne kilometraže motornog vozila nije paušalizirani zahtjev za naknadom štete, već dio zahtjeva za ispunjenjem primarne ugovorne obveze vraćanja motornog vozila u ugovorenom stanju: OLG Düsseldorf, I-24 U 44/05 od 22. studenog 2005., dostupno na: openJur, 8. siječanj 2017., § 51.

U njemačkoj pravnoj književnosti isto stajalište zastupaju, primjerice: Engel, J., loc. cit. u bilj. 3; Peters, B. u: Peters, B. i Schmid-Burgk, K., op. cit. u bilj. 3, str. 92. 
objekt leasinga po prestanku ugovora o operativnom leasingu vratiti davatelju leasinga "na način i u stanju određenim ugovorom o leasingu", pa prema tomu i u stanju koje odgovara ugovorenom ograničenju ukupne kilometraže motornog vozila.

Neprijeporno je u austrijskom i njemačkom pravu da primatelj leasinga ne odgovara davatelju leasinga za istrošenost objekta leasinga redovitom uporabom, ${ }^{52}$ a istovjetno u hrvatskom pravu izričito proizlazi iz odredbe čl. 62. st. 3. ZL-a. ${ }^{53}$ Ugovaranjem ograničenja ukupne kilometraže ugovorne strane definiraju upravo opseg prihvatljive istrošenosti motornog vozila koja je posljedica redovite uporabe motornog vozila. ${ }^{54}$

\subsection{Ostatak vrijednosti motornog vozila u ugovoru s ograničenjem kilometraže}

U ugovoru s obračunom kilometraže ugovoreno ograničenje ukupne kilometraže motornog vozila je uz ugovoreno trajanje ugovora odlučan element za utvrđivanje predvidivog ostatka vrijednosti motornog vozila, a time i za izračun naknade za leasing koja se redovito određuje umanjenjem nabavne vrijednosti motornog leasinga za iznos predvidivog ostatka vrijednosti motornog vozila. ${ }^{55}$ Ako je primatelj leasinga platio sve ugovorene mjesečne obroke naknade za leasing i po isteku ugovora davatelju leasinga vratio motorno vozilo u stanju koje odgovara ugovorenoj ukupnoj kilometraži motornog vozila, primatelj leasinga ispunio je sve svoje ugovorne obveze te davatelj leasinga nema prema njemu nikakvih zahtjeva koji bi se ticali predvidivog ostatka vrijednosti motornog vozila. ${ }^{56}$ Metoda obračuna naknada za prekoračenje i nedostizanje ugovorene ukupne kilometraže, karakteristična za ugovor s obračunom kilometraže, čini, prema stajalištima njemačke sudske prakse i pravne književnosti, suvišnim i utvrđivanje stvarnog ostatka vrijednosti motornog vozila po prestanku ugovora i specificiranje predvidivog ostatka vrijednosti motornog vozila u ugovoru prilikom njegova sklapanja. ${ }^{57}$ Stoga se u njemačkoj poslovnoj praksi iznos predvidivog

52 Usp.: Berninghaus, J. u: Büschgen, H. E., op. cit. u bilj. 3, str. 396.; Engel, J., op. cit. u bilj. 3, str. 211.; Martinek, M. i Wimmer-Leonhardt, S., Rechtsprobleme des Kfz-Leasing, u: Martinek, M. et al., op. cit. u bilj. 3, str. 544.; Schopper, A. i Skarics, F. u: Apathy, P. et al., op. cit. u bilj. 3, str. 34.; Stoffels, M. u: Staudinger, op. cit. u bilj. 3, str. 30.

53 Odredba čl. 62. st. 3. ZL-a glasi: "Primatelj leasinga ne odgovara za istrošenost objekta leasinga koja nastane njegovim redovitim korištenjem, kao ni za promjene na njemu koje su izvršene u dogovoru s davateljem leasinga."

54 Usp.: Engel, J., op. cit. u bilj. 3, str. 74.; Martinek, M. i Wimmer-Leonhardt, S. u: Martinek et al., op. cit. u bilj. 3, str. 546. U istom smislu i BGH u odluci: BGH, VIII ZR 319/85 od 15. listopada 1986., dostupno na: Jurion - das Rechtsportal, $<$ https://www.jurion.de/ $>$ (dalje u tekstu: Jurion), 8. siječnja 2017., § 28.

55 Vidi supra, bilj. 1.

56 Usp.: Engel, J., op. cit. u bilj. 3, str. 74.; Zahn, H. u: Graf von Westphalen, F., op. cit. u bilj. 3, str. 907. - 908.

57 U njemačkoj sudskoj praksi ovo stajalište zastupljeno je u odluci: BGH, VIII ZR 319/85 od 15. listopada 1986., dostupno na: Jurion, 8. siječnja 2017., § 28. Istovjetno u njemačkoj pravnoj književnosti, primjerice: Engel, J., op. cit. u bilj. 3, str. 73.; Stoffels, M. u: Staudinger, op. cit. u bilj. 3, str. 30.; Zahn, H. u: Graf von Westphalen, F., op. cit. u bilj. 3, str. 946. 
ostatka vrijednosti motornog vozila često ni ne naznačuje u ugovoru s obračunom kilometraže. ${ }^{58}$ Nasuprot tome, ugovori o operativnom leasingu koji se sklapaju u analiziranom modelu ugovora iz hrvatske poslovne prakse redovito sadrže i naznaku iznosa predvidivog ostatka vrijednosti motornog vozila. ${ }^{59}$ Oni takvu naznaku i moraju sadržavati jer je odredba o ostatku vrijednosti objekta leasinga dio obaveznog sadržaja ugovora o operativnom leasingu propisanog odredbom čl. 52. st. 3. ZL-a.

Odredba čl. 52. st. 3. ZL-a samo propisuje da ugovor o operativnom leasingu mora sadržavati i naznaku ostatka vrijednosti objekta leasinga, no iz te odredbe, a ni iz ostalih odredaba ZL-a, ne proizlazi bilo kakva obveza primatelja leasinga u vezi s ostatkom vrijednosti objekta leasinga. Posebno ne proizlazi obveza primatelja leasinga nadoknaditi davatelju leasinga eventualnu razliku između ostatka vrijednosti objekta leasinga naznačenog u ugovoru o operativnom leasingu i iznosa ostvarenog unovčenjem objekta leasinga po prestanku ugovora o operativnom leasingu. Rizik unovčenja objekta leasinga $u$ analiziranom modelu ugovora o operativnom leasingu iz hrvatske poslovne prakse isključivo je na davatelju leasinga ${ }^{60}{ }^{6}$ što je ključno obilježje i ugovora s obračunom kilometraže iz austrijske i njemačke poslovne prakse ${ }^{61}$

U austrijskoj i njemačkoj poslovnoj praksi davatelj leasinga uobičajeno se osigurava od rizika unovčenja motornog vozila putem tzv. buy-back ili reotkupne garancije koju mu izdaje dobavljač objekta leasinga (njem. Rücknahmegarantie). ${ }^{62}$ Sklapanje ugovora o kupoprodaji objekta leasinga uz izdavanje buy-back garancije dobavljača objekta leasinga često je i u poslu operativnog leasinga u hrvatskoj poslovnoj praksi. Tom se garancijom dobavljač objekta leasinga obvezuje davatelju leasinga kupiti objekt leasinga od davatelja leasinga za unaprijed utvrđenu cijenu koja redovito odgovara iznosu predvidivog ostatka vrijednosti objekta leasinga naznačenog u ugovoru o operativnom leasingu. ${ }^{63}$

\subsection{Naknada za smanjenje vrijednosti motornog vozila}

Okolnost da je rizik unovčenja motornog vozila u ugovoru s obračunom kilometraže na davatelju leasinga ne znači i da primatelj leasinga nije odgovoran

58 Usp.: Engel, J., op. cit. u bilj. 3, str. 281.

59 Analiza pojedinih ugovora o operativnom leasingu sklopljenih uz primjenu OU ALD-a pokazuje da je iznos ostatka vrijednosti motornog vozila redovito sadržan u ugovoru o leasingu.

60 Vidi supra, bilj. 15 - 19.

61 Za stajališta austrijske i njemačke pravne književnosti vidi supra, bilj. 28. Rizik unovčenja motornog vozila nakon prestanka ugovora s obračunom kilometraže isključivo je rizik davatelja leasinga i prema njemačkoj sudskoj praksi: BGH, VIII ZR 367/03 od 14. srpnja 2004., dostupno na: openJur, 8. siječnja 2017., §29.

62 Usp.: Engel, J., loc. cit. u bilj. 3; Grundmann, W., op. cit. u bilj. 2, str. 106.; Kratzer, J. i Kreuzmair, B., op. cit. u bilj. 2, str. 73.; Martinek, M. i Wimmer-Leonhardt, S. u: Martinek, M. et al., loc. cit. u bilj. 51; Peters, B. u: Peters, B. i Schmid-Burgk, K., op. cit. u bilj. 3, str. 92.; Stoffels, M. u: Staudinger, loc. cit. u bilj. 3.

63 Ugovor o kupoprodaji objekta leasinga koji sklapaju dobavljač objekta leasinga kao prodavatelj i davatelj leasinga kao kupac, uz izdavanje buy-back garancije dobavljača objekta leasinga, redovito je ugovor o kupoprodaji s posebnom pogodbom nazadprodaje. Iscrpnije o tome vidi u: Tot, I., op. cit. u bilj. 1, str. 379. - 380. 
davatelju leasinga za smanjenje vrijednosti motornog vozila koje bi bilo posljedica oštećenja i istrošenosti nastale uporabom koja prelazi okvire redovite uporabe motornog vozila. Primatelj leasinga se ugovorom s obračunom kilometraže redovito obvezuje po prestanku ugovora vratiti davatelju leasinga motorno vozilo u ugovorenom stanju: stanju koje odgovara njegovoj starosti i ugovorenoj kilometraži, neoštećeno i sigurno za prijevoz i korištenje. ${ }^{64} \mathrm{Za}$ slučaj da primatelj leasinga vrati davatelju leasinga motorno vozilo u stanju koje ne odgovara ugovorenom stanju, ugovorne odredbe ugovora s obračunom kilometraže redovito sadrže obvezu primatelja leasinga platiti davatelju leasinga posebnu naknadu za smanjenje vrijednosti motornog vozila (njem. Minderwertausgleich) ${ }^{65}$

Za pitanje je li vrijednost motornog vozila smanjena zbog oštećenja i istrošenosti nastale prekomjernom uporabom motornog vozila odlučna su ugovorena mjerila o tomu kakvo stanje motornog vozila i kakva oštećenja se smatraju prihvatljivim stanjem i oštećenjima motornog vozila. ${ }^{66}$ Nakon prestanka ugovora s obračunom kilometraže i vraćanja motornog vozila davatelju leasinga pristupa se pregledu motornog vozila radi utvrđivanja stanja motornog vozila i utvrđivanja popravaka koje je potrebno izvršiti da bi se motorno vozilo dovelo u prihvatljivo stanje sukladno ugovorenim mjerilima. Međutim, često ugovorne odredbe ne sadrže detaljna mjerila za razgraničenje istrošenosti koja je posljedica redovite uporabe motornog vozila, za koju primatelj leasinga ne odgovara davatelju leasinga, od istrošenosti koja je posljedica prekomjerne uporabe motornog vozila, za koju je primatelj leasinga obvezan platiti davatelju leasinga naknadu za smanjenje vrijednosti motornog vozila. Poteškoće koje u vezi s tim razgraničenjem nastaju u poslovnoj praksi označavaju se u njemačkoj literaturi i "Ahilovom petom ugovora o leasingu motornog vozila s obračunom kilometraže". ${ }^{67}$

Naknada za smanjenje vrijednosti motornog vozila koju se primatelj leasinga obvezuje platiti davatelju leasinga odnosi se redovito na troškove popravaka koji su nužni da bi se motorno vozilo dovelo u prihvatljivo stanje definirano ugovorom. Tu je naknadu, prema stajalištima njemačke sudske prakse i pravne književnosti, potrebno utvrditi u potpunosti neovisno o kalkuliranom, predvidivom ostatku vrijednosti motornog vozila te neovisno o iznosu postignutom unovčenjem motornog vozila poslije prestanka ugovora. ${ }^{68}$ Obveza primatelja leasinga naknaditi smanjenu vrijednost

64 Usp.: Berninghaus, J. u: Büschgen, H. E., op. cit. u bilj. 3, str. 397.; Engel, J., op. cit. u bilj. 3, str. 211.; Martinek, M. i Wimmer-Leonhardt, S. u: Martinek, M. et al., loc. cit. u bilj. 34; Stoffels, M. u: Staudinger, op. cit. u bilj. 3, str. 30.

65 Usp.: Engel, J., op. cit. u bilj. 3, str. 214.; Koch, J., u: MünchKomm III, op. cit. u bilj. 3, Rn. 136.; Peters, B. u: Peters, B. i Schmid-Burgk, K., op. cit. u bilj. 3, str. 92.; Scharff, U. u: Beckmann, H. i Scharff, U., loc. cit. u bilj. 3; Schopper, A. i Skarics, F. u: Apathy, P. et al., op. cit. u bilj. 3, str. 34.; Stoffels, M. u: Staudinger, op. cit. u bilj. 3, str. 30.; Zahn, H. u: Graf von Westphalen, F., op. cit. u bilj. 3, str. 893.

66 Usp.: Engel, J., op. cit. u bilj. 3, str. 215.; Stoffels, M. u: Staudinger, op. cit. u bilj. 3, str. 30. - 31.

67 Engel, J., op. cit. u bilj. 3, str. 215.

68 O potrebi utvrđivanja naknade za smanjenje vrijednosti motornog vozila neovisno o predvidivom ostatku vrijednosti motornog vozila i iznosu postignutog unovčenjem motornog vozila vidi odluke iz njemačke sudske prakse: BGH, VIII ZR 177/99 od 1. ožujka 2000., dostupno na: openJur, 8. siječnja 2017., § 26.; BGH, VIII ZR 22/12 od 14. studenog 2012., dostupno na: 
motornog vozila ne utječe na raspodjelu rizika unovčenja karakterističnu za ugovor s obračunom kilometraže: rizik unovčenja motornog vozila i dalje je na davatelju leasinga. Primatelj leasinga nije obvezan naknaditi davatelju leasinga razliku između višeg predvidivog ostatka vrijednosti motornog vozila i nižeg iznosa cijene ostvarene prodajom motornog vozila po prestanku ugovora, ali je obvezan naknaditi smanjenu vrijednost motornog vozila zbog prekomjerne uporabe i ako davatelj leasinga unatoč oštećenju motornog vozila unovčenjem može ostvariti kalkulirani, predvidivi ostatak vrijednosti motornog vozila. ${ }^{69}$

U hrvatskom pravu, obveza primatelja leasinga po prestanku ugovora o operativnom leasingu vratiti objekt davatelju leasinga u ugovorenom stanju proizlazi i iz odredbe čl. 62. st. 1. ZL-a. ${ }^{70}$ Prema odredbi čl. 62. st. 3. ZL-a, primatelj leasinga ne odgovara za istrošenost objekta leasinga koja nastane njegovom redovitom uporabom, jednako kao što ni najmoprimac ne odgovara za istrošenost iznajmljene stvari nastalu njezinom redovitom uporabom. ${ }^{71}$ Međutim, dok najmoprimac prema odredbi čl. 566. st. 2. ZOO-a ne odgovara ni za oštećenja iznajmljene stvari koja su posljedica dotrajalosti, odredba čl. 62. st. 3. ZL-a ne predviđa isključenje odgovornosti primatelja leasinga za oštećenja objekta leasinga koja su posljedica dotrajalosti. Primatelj leasinga odgovara i za takva oštećenja objekta leasinga, što je posljedica za ugovor o leasingu tipičnih obveza primatelja leasinga održavati objekt leasinga u stanju podobnom za ugovorenu uporabu i izvršavati potrebne popravke, a koje obveze su u ugovoru o najmu obveze najmodavca, a ne najmoprimca. ${ }^{72}$ Za oštećenja objekta leasinga primatelj leasinga odgovara neovisno o tome jesu li ona nastala njegovom krivnjom ili su nastala zbog slučaja ili više sile, a što je posljedica za ugovor o leasingu tipičnog prijelaza rizika slučajne propasti ili oštećenja objekta leasinga s davatelja leasinga na primatelja leasinga, koji za ugovor o najmu nije karakterističan. ${ }^{73}$

openJur, 8. siječnja 2017., § 32.; BGH, VIII ZR 265/12 od 24. travnja 2013., dostupno na: openJur, 8. siječnja 2017., § 23.; BGH, VIII ZR 336/12 od 24. travnja 2013., dostupno na: openJur, 8. siječanj 2017., § 34. Istovjetno u njemačkoj pravnoj književnosti, primjerice: Engel, op. cit. u bilj. 3, str. 214.; Stoffels, M. u: Staudinger, loc. cit. u bilj. 3; Zahn, H. u: Graf von Westphalen, F., op. cit. u bilj. 3, str. 946.

69 BGH, VIII ZR 334/12 od 17. srpnja 2013., dostupno na: openJur, 8. siječnja 2017., § 18.

70 Odredba čl. 62. st. 1. ZL-a glasi: "Primatelj leasinga dužan je po prestanku ugovora o leasingu bez odgađanja objekt leasinga vratiti davatelju leasinga na način i u stanju određenim ugovorom o leasingu, osim ako je sukladno ugovoru o leasingu ispunio uvjete kojima stječe pravo vlasništva nad objektom leasinga, pravo produženja ugovora o leasingu ili je za taj objekt leasinga sklopljen novi ugovor o leasingu". Odredba čl. 62. st. 1. ZL-a primjenjuje se i na ugovor o financijskom leasingu i na ugovor o operativnom leasingu. Za razliku od posla financijskog leasinga, u poslu operativnog leasinga uobičajeno je da primatelj leasinga nema opciju kupnje objekta leasinga ni drugo pravo temeljem kojeg bi bio ovlašten na uporabu objekta leasinga nakon proteka vremena na koje je ugovor o operativnom leasingu sklopljen.

71 Prema odredbi čl. 566. st. 2. ZOO-a.

72 Iscrpnije o obvezama primatelja leasinga održavati objekt leasinga i izvršavati potrebne popravke objekta leasinga tijekom trajanja ugovora o leasingu, nasuprot usporedivim obvezama najmodavca u ugovoru o najmu, vidi u: Tot, I., op. cit. u bilj. 1, str. 226. - 231.

73 Istovjetno i u njemačkom pravu, o čemu vidi, primjerice, u: Engel, J., op. cit. u bilj. 3, str. 212.; Martinek, M. i Wimmer-Leonhardt, S. u: Martinek, M. et al., loc. cit. u bilj. 34. Iscrpnije o riziku slučajne propasti ili oštećenja objekta leasinga i riziku slučajne propasti ili oštećenja 
Obveza vraćanja motornog vozila u ugovorenom stanju i obveza plaćanja naknade za smanjenje vrijednosti motornog vozila karakteristične su i za analizirani model ugovora o operativnom leasingu iz hrvatske poslovne prakse. Primatelj leasinga obvezuje se ugovornim odredbama motorno vozilo vratiti davatelju leasinga u "urednom stanju", ${ }^{74}$ pri čemu se uredno stanje definira na način koji je uobičajen i u njemačkoj poslovnoj praksi. ${ }^{75}$ Pri vraćanju motornog vozila davatelju leasinga, stanje motornog vozila, oštećenja i potreba popravaka utvrđuju se pregledom motornog vozila, a sukladno ugovorenim kriterijima prihvatljivog stanja sadržanim u posebnoj ispravi koja je sastavni dio ugovora o operativnom leasingu. ${ }^{76} \mathrm{Za}$ oštećenja i istrošenost motornog vozila uporabom koja se prema ugovorenim kriterijima prihvatljivog stanja ne smatra redovitom uporabom motornog vozila primatelj leasinga obvezuje se davatelju leasinga naknaditi pregledom vozila "utvrđeni iznos umanjenje vrijednosti vozila". ${ }^{77}$

\section{UGOVOR O OPERATIVNOM LEASINGU U KOJEMU JE PRIMATELJ LEASINGA NOSITELJ RIZIKA UNOVČENJA MOTORNOG VOZILA}

Ugovor o operativnom leasingu motornog vozila javlja se u hrvatskoj poslovnoj praksi i u ugovornom modelu u kojemu je primatelj leasinga nositelj rizika unovčenja motornog vozila, odnosno u kojemu se primatelj leasinga obvezuje davatelju leasinga nadoknaditi razliku između višeg iznosa predvidivog ostatka vrijednosti motornog vozila i nižeg iznosa cijene ostvarene prodajom motornog vozila nakon prestanka ugovora o operativnom leasingu.

Odredbama općih uvjeta poslovanja za ugovore o operativnom leasingu jednoga hrvatskog leasing društva primatelj leasinga obvezuje se, ako je vrijednost motornog vozila nakon redovnog isteka ugovora o operativnom leasingu "manja od ostatka vrijednosti navedenog u Ugovoru o leasingu", naknaditi davatelju leasinga "svu nastalu štetu", a "osobito razliku između ostatka vrijednosti i postignute prodajne

predmeta najma u hrvatskom pravu vidi u: Tot, I., op. cit. u bilj. 1, str. 231. - 237.

74 Prema odredbi čl. 24.1. OU ALD.

75 Odredba čl. 24.3. OU ALD-a predviđa da motorno vozilo "mora biti u stanju koje odgovara njegovoj starosti i ugovorenoj kilometraži” te da "mora biti neoštećeno i sigurno za prijevoz i korištenje", a što je uobičajen način na koji se određuje ugovoreno stanje motornog vozila u njemačkoj poslovnoj praksi, o čemu vidi supra, bilj. 63 .

76 Prema odredbi čl. 24.4. OU ALD-a, "odabrana treća stručna osoba sačinit će pisanu ispravu o pregledu vozila radi definiranja stanja vozila, postojanja oštećenja i identificiranja potrebnih popravaka, sve sukladno kriterijima prihvatljivog stanja odnosno neprihvatljivih oštećenja vozila prilikom njegovog povrata definiranih u dokumentu "Upute za korisnika" koji je privitkom Ugovoru o operativnom leasingu". Kriteriji prihvatljivog, odnosno neprihvatljivog stanja motornog vozila detaljno su opisani i ilustrirani fotografijama u: ALD Automotive d.o.o., Upute za korisnika, <http://www.aldautomotive.hr/Portals/croatia/adam/Content/ Bz6fDBAwPUyZ W0TE7ZCkGg/Free_Text/UPUTA\%20ZA\%20KORISNIKE-1-2-3.pdf>, 7. siječnja 2017., str. 23. - 28.

77 Prema odredbi čl. 24.4. OU ALD. 
cijene" ${ }^{78}$ Vrijednost motornog vozila nakon redovnog isteka ugovora o operativnom leasingu utvrđuje se procjenom procjenitelja ili vještaka kojeg je ovlašten odrediti davatelj leasinga, a ta je procjena "polazište za određivanje" "prodajne cijene". 79 Vraćeno motorno vozilo procjenjuje se i u slučaju prijevremenog prestanka ugovora o leasingu "kako bi se utvrdila njegova vrijednost koja će biti polazište za određivanje daljnje prodajne cijene", odnosno "cijene za davanje objekta dalje u leasing najam, ili zakup" ${ }^{80}$ Prestane li ugovor o operativnom leasingu prijevremeno jednostranim raskidom ugovora koji je izjavio davatelj leasinga, u konačnom obračunu "Primatelju leasinga će se obračunati razlika između nefakturiranih diskontiranih neto potraživanja uvećanih za ugovoreni ostatak vrijednosti (preostala vrijednost ugovora) i neto prodajne cijene objekta leasinga trećoj osobi" ${ }^{81}$

Iz analize ugovornih odredaba ovih općih uvjeta poslovanja za ugovore o operativnom leasingu proizlazi da u ugovorima o operativnom leasingu sklopljenim uz primjenu tih općih uvjeta poslovanja rizik unovčenja objekta leasinga isključivo snosi primatelj leasinga, i u slučaju redovnog prestanka ugovora o operativnom leasingu protekom vremena na koje je ugovor sklopljen, i u slučaju prijevremenog prestanka ugovora o operativnom leasingu prije proteka vremena na koje je sklopljen ugovor.

Ovaj ugovorni model ugovora o operativnom leasingu iz hrvatske poslovne prakse usporediv je s modelom ugovora o leasingu motornog vozila kojeg se u austrijskoj i njemačkoj poslovnoj praksi naziva ugovorom s obračunom ostatka vrijednosti (njem. Vertrag mit Restwertabrechnung), ${ }^{82}$ a za koji je karakteristično da je ugovornim odredbama rizik unovčenja motornog vozila prenesen na primatelja leasinga. Stoga se u nastavku analizira tretman tog ugovora u austrijskom i njemačkom pravu, te ocjenjuje mogu li se poredbenopravna rješenja u vezi s tim ugovorom primijeniti i na opisani model ugovora o operativnom leasingu iz hrvatske poslovne prakse. Posebno se analizira i dvojbeni računovodstveni tretman takvih ugovora o operativnom leasingu iz hrvatske poslovne prakse.

\subsection{Ostatak vrijednosti u ugovoru s obračunom ostatka vrijednosti}

Ugovor o leasingu motornog vozila s obračunom ostatka vrijednosti se u austrijskoj i njemačkoj poslovnoj praksi redovito sklapa na određeno vrijeme čijim istekom je primatelj leasinga obvezan vratiti motorno vozilo davatelju leasinga. Ugovor s obračunom ostatka vrijednosti, istovjetno kao i ugovor s obračunom kilometraže,

78 Prema odredbama čl. 20.3. OU OTP.

79 Ibid.

80 Prema odredbama čl. 20.4. OU OTP.

81 Prema odredbama čl. 23.2. OU OTP.

82 Usp.: Martinek, M. i Wimmer-Leonhardt, S. u: Martinek et al., op. cit. u bilj. 3, str. 547. Ovaj ugovorni model naziva se i: ugovorom s jamstvom ostatka vrijednosti (njem. Vertrag mit Restwertgarantie; primjerice, u: Stoffels, M. u: Staudinger, op. cit. u bilj. 3, str. 153.; Zahn, H. u: Graf von Westphalen, F., op. cit. u bilj. 3, str. 891.), ugovorom s osiguranjem ostatka vrijednosti (njem. Vertrag mit Restwertabsicherung; primjerice u: Berninghaus, J. u: Büschgen, H. E., op. cit. u bilj. 3, str. 394.) te ugovorom s obračunom rabljenog vozila (njem. Vertrag mit Gebrauchtwagenabrechnung; primjerice, u: Engel, J., op. cit. u bilj. 3, str. 68.). 
redovito ne sadrži opciju kupnje ni opciju produženja ugovora ugovorenu u korist primatelja leasinga ${ }^{83}$ Investicijski troškovi davatelja leasinga se i u ovom ugovornom modelu dijelom nadoknađuju putem mjesečnih obroka naknade za leasing, a dijelom unovčenjem motornog vozila nakon prestanka ugovora. Kao i u ugovoru s obračunom kilometraže, naknada za leasing računa se tako da se od nabavne vrijednosti motornog vozila oduzima iznos ostatka vrijednosti koje bi motorno vozilo predvidivo trebalo imati po isteku ugovora s obračunom ostatka vrijednosti. Međutim, dok se u ugovoru s obračunom kilometraže iznos predvidivog ostatka vrijednosti motornog vozila ne mora nužno naznačiti u ugovoru, ostatak vrijednosti motornog vozila u ugovoru s obračunom kilometraže iznos je koji ugovorne strane sporazumno utvrđuju pri sklapanju ugovora i koji se redovito i navodi u ugovoru. ${ }^{84}$

Karakteristično je za ugovor s obračunom ostatka vrijednosti da primatelj leasinga jamči davatelju leasinga da će stvarna vrijednost motornog vozila po prestanku ugovora i vraćanju motornog vozila davatelju leasinga odgovarati najmanje ugovorenom ostatku vrijednosti motornog vozila. ${ }^{85}$ Ostvari li davatelj leasinga prodajom motornog vozila cijenu koja je niža od iznosa ugovorenog ostatka vrijednosti, primatelj leasinga je obvezan naknaditi davatelju leasinga razliku, zbog čega je rizik unovčenja motornog vozila u ovom ugovornom modelu na primatelju leasinga. ${ }^{86}$

U kontekstu hrvatskoga prava potrebno je, još jednom, naglasiti da se ni iz odredbe čl. 52. st. 3. t. 2. ZL-a niti iz odredbe čl. 12. Pravilnika ne bi moglo zaključivati da primatelj leasinga ima prema davatelju leasinga bilo kakvu obvezu u vezi s ostatkom vrijednosti objekta leasinga nakon prestanka ugovora o operativnom leasingu. Zakonski model za ugovor o operativnom leasingu ne uređuje međusobna prava i obveze ugovornih strana za slučaj da je stvarna vrijednost objekta leasinga po isteku ugovora o operativnom leasingu manja od ugovorenog ostatka vrijednosti objekta leasinga, kao ni za slučaj da je davatelj leasinga prodajom objekta leasinga po isteku ugovora o operativnom leasingu ostvario cijenu nižu od ugovorenog ostatka vrijednosti objekta leasinga.

U austrijskom i njemačkom pravu je u vezi s jamstvom primatelja leasinga za ostatak vrijednosti, karakterističnim za ugovor s obračunom ostatka vrijednosti, odnosno u vezi s primarnom ugovornom obvezom primatelja leasinga nadoknaditi davatelju leasinga razliku između višeg iznosa ugovorenog ostatka vrijednosti i nižeg iznosa postignutog unovčenjem objekta leasinga, ustanovljena i posebna sporedna obveza davatelja leasinga: $\mathrm{s}$ dužnom pažnjom nastojati unovčiti objekt leasinga što

83 Usp.: Engel, J., op. cit. u bilj. 3, str. 68.

84 Usp.: Berninghaus, J. u: Büschgen, H. E., op. cit. u bilj. 3, str. 394.; Engel, J., op. cit. u bilj. 3, str. 68.; Martinek, M. i Wimmer-Leonhardt, S. u: Martinek et al., op. cit. u bilj. 34, str. 530.

85 Usp.: Berninghaus, J. u: Büschgen, H. E., op. cit. u bilj. 3, str. 394.; Engel, J., op. cit. u bilj. 3, str. 69.; Stoffels, M. u: Staudinger, op. cit. u bilj. 3, str. 153.

86 Usp.: Berninghaus, J. u: Büschgen, H. E., op. cit. u bilj. 3, str. 394.; Engel, J., op. cit. u bilj. 3, str. 69. i 228.; Fink, C., loc. cit. u bilj. 2; Martinek, M. i Wimmer-Leonhardt, S. u: Martinek et al., op. cit. u bilj. 34, str. 530.; Oechsler, J., op. cit. u bilj. 28, str. 277.; Riedler, A. u: Apathy, P. i Riedler, A., op. cit. u bilj. 2, str. 121.; Schopper, A. i Skarics, F. u: Apathy, P. et al., op. cit. u bilj. 3, str. 24.; Stoffels, M. u: Staudinger, op. cit. u bilj. 3, str. 153. 
je najbolje moguće (njem. mit zumutbarer Sorgfalt um die bestmögliche Verwertung der Leasingsache zu bemühen). ${ }^{87}$ Da bi ispunio obvezu unovčiti motorno vozilo "što je najbolje moguće", davatelj leasinga mora aktivno na tržištu tražiti najbolju priliku za unovčenje motornog vozila, prikupljati ponude više potencijalnih kupaca i prihvatiti onu kojom je ponuđena najviša cijena. Tu obvezu on nije ispunio ako je motorno vozilo prodao prvom potencijalnom kupcu za iznos koji odgovara vrijednosti motornog vozila utvrđenog procjenom po isteku ugovora s obračunom ostatka vrijednosti. Procijenjena vrijednost motornog vozila je samo mjerilo za ocjenu je li davatelj leasinga protivno načelu savjesnosti i poštenja prodao motorno vozilo za suviše nisku cijenu. ${ }^{88} \mathrm{Ne}$ ispuni li davatelj leasinga obvezu unovčiti motorno vozilo "što je najbolje moguće", odgovoran je primatelju leasinga za štetu. ${ }^{89}$

Postojanje obveze davatelja leasinga unovčiti motorno vozilo "što je najbolje moguće" prihvatljivo je i u kontekstu hrvatskoga prava. Unovčenje motornog vozila "prvom prilikom", za iznos koji ne bi predstavljao najvišu moguću cijenu koju je moguće postignuti na tržištu, a zatim fakturiranje primatelju leasinga razlike između iznosa ostvarenog prodajom i iznosa ugovorenog ostatka vrijednosti motornog vozila, predstavljalo bi postupanje davatelja leasinga koje bi bilo protivno i načelu savjesnosti i poštenja, kao i načelu zabrane prouzročenja štete.

U austrijskoj i njemačkoj poslovnoj praksi, ugovorom s obračunom ostatka vrijednosti primatelj leasinga ne obvezuje se platiti davatelju leasinga posebnu naknadu za smanjenje vrijednosti motornog vozila za slučaj da po isteku ugovora motorno vozilo bude vraćeno u stanju koje ne odgovara ugovorenom urednom stanju, a koja je karakteristična za ugovor s obračunom kilometraže. Razlog tomu je taj što se takvo smanjenje vrijednosti po prestanku ugovora s obračunom ostatka vrijednosti davatelju leasinga nadoknađuje putem naknade razlike između iznosa prodajom ostvarene cijene i iznosa ugovorenog ostatka vrijednosti motornog vozila. ${ }^{90}$

U austrijskoj i njemačkoj poslovnoj praksi, ostvari li davatelj leasinga prodajom motornog vozila višak u odnosu na ugovoreni ostatak vrijednosti, taj se višak (njem. Mehrerlös) dijeli između davatelja leasinga i primatelja leasinga sukladno odredbama

87 O sporednoj obvezi davatelja leasinga unovčiti objekt leasinga "što je najbolje moguće" vidi u odlukama iz njemačke sudske prakse: BGH, VIII ZR 148/84 od 12. lipnja 1985., dostupno na: Jurion, 8. siječnja 2017., § 47.; BGH, VIII ZR 296/89 od 10. listopada 1990., dostupno na: Jurion, 8. siječnja 2017., § 23.; BGH, VIII ZR 39/91 od 27. studenog 1991., dostupno na: Jurion, 8. siječnja 2017., § 10.; BGH, VIII ZR 312/96 od 4. lipnja 1997., dostupno na: Jurion, 8. siječnja 2017., § 18.

Istovjetno i austrijskoj sudskoj praksi, primjerice, u: OGH, 8 Ob 38/90 od 17. siječnja 1991., dostupno na: RIS, 8. siječnja 2017.

U austrijskoj i njemačkoj pravnoj književnosti, primjerice: Engel, J., op. cit. u bilj. 3, str. 69. i 230. - 231.; Martinek, M. i Wimmer-Leonhardt, S. u: Martinek et al., op. cit. u bilj. 34, str. 530.; Martinek, M. i Wimmer-Leonhardt, S. u: Martinek et al., op. cit. u bilj. 3, str. 548.; Schopper, A. i Skarics, F. u Apathy, P. et al., op. cit. u bilj. 3, str. 186.; Stoffels, M. u: Staudinger, op. cit. u bilj. 3, str. 154 .

88 Engel, J., op. cit. u bilj. 3, str. 228.

89 Usp.: ibid., str. 230. - 231.; Stoffels, M. u: Staudinger, op. cit. u bilj. 3, str. 154.

90 Usp.: Engel, J., op. cit. u bilj. 3, str. 69. i 229.; Martinek, M. i Wimmer-Leonhardt, S. u: Martinek et al., op. cit. u bilj. 3, str. 547.; Stoffels, M. u: Staudinger, op. cit. u bilj. 3, str. 143. 
ugovora s obračunom ostatka vrijednosti, $i$ to redovito na način da primatelju leasinga pripada $75 \%$, a davatelju leasingu $25 \%$ ostvarenog viška.${ }^{91}$ Raspodjela viška ostvarenog prodajom u ovim omjerima uvjetovana je poreznopravnim propisima. ${ }^{92}$

$\mathrm{U}$ analiziranom modelu ugovora o operativnom leasingu iz hrvatske poslovne prakse, za primatelja leasinga nije ugovorom ustanovljeno pravo sudjelovanja $\mathrm{u}$ raspodjeli viška ostvarenog prodajom motornog vozila. ${ }^{93}$ Ta okolnost sama po sebi ne znači da postoji značajna neravnoteža prava i obveza ugovornih strana ugovora o operativnom leasingu u kojemu je rizik unovčenja motornog vozila na primatelju leasinga. ${ }^{94} \mathrm{U}$ pojedinim odlukama iz hrvatske sudske prakse opravdano su utvrđene ništetnima odredbe općih uvjeta poslovanja za ugovore o operativnom leasingu kojima je, suprotno svrsi ugovorenog ostatka vrijednosti objekta leasinga kao iznosa koji se ne nadoknađuje naknadom za leasing, davatelj leasinga bio ovlašten u slučaju prijevremenog prestanka ugovora zahtijevati od primatelja leasinga i plaćanje ugovorenog ostatka vrijednosti objekta leasinga. ${ }^{95} \mathrm{U}$ dostupnoj i objavljenoj hrvatskoj sudskoj praksi nisu pronađene odluke u kojima bi se ocjenjivala valjanost odredaba općih uvjeta poslovanja za ugovore o operativnom leasingu kojima se primatelj leasinga obvezuje nadoknaditi davatelju leasinga razliku između višeg iznosa ugovorenog ostatka vrijednosti i nižeg iznosa ostvarenog unovčenjem objekta leasinga.

Ugovorna odredba općih uvjeta poslovanja kojom se primatelj leasinga obvezao davatelju leasinga naknaditi razliku između ugovorenog ostatka vrijednosti i cijene ostvarene prodajom motornog vozila proizvodi pravne učinke, prema stajalištima

91 Usp.: Berninghaus, J. u: Büschgen, H. E., op. cit. u bilj. 3, str. 394.; Engel, J., op. cit. u bilj. 3, str. 69. i 228.; Martinek, M. i Wimmer-Leonhardt, S. u: Martinek et al., op. cit. u bilj. 34, str. 530.; Stoffels, M. u: Staudinger, op. cit. u bilj. 3, str. 153.

92 Da bi se maksimizirale računovodstvene i poreznopravne prednosti ugovora o leasingu u odnosu na ugovor o kupoprodaji, ugovorne strane ugovora o leasingu nastoje ugovor strukturirati na način da se objekt leasinga i računovodstveno i poreznopravno pripiše davatelju leasinga kao ekonomskom vlasniku objekta leasinga. Za ugovor s obračunom ostatka vrijednosti će poreznopravno pripisivanje objekta leasinga davatelju leasinga, a time i računovodstveno priznavanje objekta leasinga kao imovine u bilanci davatelja leasinga, prema poreznopravnim propisima austrijskog i njemačkog prava, biti moguće samo ako je primatelj leasinga ovlašten na najviše $75 \%$ razlike između nižeg iznosa ostatka vrijednosti i višeg iznosa cijene ostvarene unovčenjem objekta leasinga. Iscrpno o tome vidi u: Tot, I., op. cit. u bilj. 1, str. 126. - 148.

93 U OU OTP nisu sadržane odredbe iz kojih bi proizlazilo da primatelj leasinga ima pravo na udio u višku ostvarenom prodajom objekta leasinga. U vezi s prodajom objekta leasinga nakon raskida ugovora o operativnom leasingu, odredbom čl. 19.3. OU OTP ugovoreno je da "eventualnu pozitivnu razliku ostvarenu prodajom ili davanjem u leasing najam ili zakup objekta leasinga (ukoliko se ista utvrdi konačnim obračunom) zadržava Davatelj leasinga".

94 Na istovjetno u kontekstu njemačkoga prava ukazuje i: Zahn, H. u: Graf von Westphalen, F., op. cit. u bilj. 3, str. 892.

95 Ništetnost odredaba općih uvjeta poslovanja za ugovore o operativnom leasingu kojima je bila ugovorena obveza primatelja leasinga platiti davatelju leasinga iznos ugovorenog ostatka vrijednosti utvrđena je u odlukama: Općinski sud u Samoboru, Povrv-1691/12 od 6. lipnja 2014. (neobjavljena); Trgovački sud u Zagrebu, P-481/2013 od 7. srpnja 2014. (neobjavljena); Županijski sud u Bjelovaru, Gž-2540/11-3 od 1. ožujka 2012., dostupno na: Portal IUS-INFO, < http://www.iusinfo.hr/>, 7. siječnja 2017. 
njemačke sudske prakse i pravne književnosti, samo ako je davatelj leasinga jasno ukazao primatelju leasinga na to da primatelj leasinga snosi rizik unovčenja motornog vozila. Taj zahtjev transparentnosti ispunjen je samo ako je takva obveza primatelja leasinga naznačena i u ispravi ugovora o leasingu sklopljenog uz primjenu općih uvjeta poslovanja, $\mathrm{i}$ to na prednjoj strani isprave. ${ }^{96}$

Za razliku od njemačkog prava, načelo transparentnosti u hrvatskom pravu nije samostalni kriterij definiranja nepoštenosti ugovorne odredbe. ${ }^{97}$ Međutim, transparentnost je jedna od temeljnih dužnosti koje za sastavljača ugovora proizlaze iz načela savjesnosti i poštenja, pa će činjenica da određena ugovorna odredba nije jasna, razumljiva ili uočljiva utjecati na ocjenu je li ponašanje sastavljača ugovora bilo u skladu s načelom savjesnosti i poštenja. ${ }^{98}$ Stoga bi i hrvatska sudska praksa, u odlukama u kojima bi ocjenjivala valjanost odredaba općih uvjeta poslovanja za ugovore o operativnom leasingu kojima se rizik unovčenja objekta leasinga prenosi na primatelja leasinga, uz okolnost da primatelj leasinga ugovorom o operativnom leasingu redovito nije ovlašten na opciju kupnje objekta leasinga i druge relevantne okolnosti, trebala voditi računa i o tomu jesu li odredbe o obvezama primatelja leasinga u vezi s unovčenjem objekta leasinga bile primatelju leasinga lako uočljive.

\subsection{Računovodstveni tretman ugovora s obračunom ostatka vrijednosti}

U austrijskom i njemačkom pravu, motorno vozilo koje je objektom leasinga u ugovoru s obračunom ostatka vrijednosti bi se primjenom koncepta ekonomskog vlasništva imalo poreznopravno i računovodstveno pripisati davatelju leasinga kao ekonomskom vlasniku objekta leasinga. ${ }^{99}$ Za računovodstveni tretman ugovora o leasingu u austrijskom i njemačkom pravu relevantni su prije svega nacionalni računovodstveni standardi, a ne MRS $17 .{ }^{100}$ Ugovori s obračunom ostatka vrijednosti

96 Ovo stajalište izraženo je u njemačkoj sudskoj praksi u odlukama: OLG Karlsruhe, 6 U 139/84 od 23. travnja 1986., dostupno na: Jurion, 8. siječnja 2017.; OLG Dresden, 8 U 339/00 od 28. lipnja 2000., dostupno na: Judicialis - Rechtsprechung, <http://www.judicialis.de/> (dalje u tekstu: Judicialis), 8. siječnja 2017.

U njemačkoj pravnoj književnosti vidi, primjerice: Berninghaus, J. u: Büschgen, H. E., op. cit. u bilj. 3, str. 396.; Engel, J., op. cit. u bilj. 3, str. 71., 228. i 257.; Martinek, M. i WimmerLeonhardt, S. u: Martinek et al., op. cit. u bilj. 50, str. 542. - 543.; Stoffels, M. u: Staudinger, op. cit. u bilj. 3, str. 155 .

97 Baretić, M. i Markovinović, H., u: Barbić, J. i Giunio, M., op. cit. u bilj. 48, str. 101.

98 Ibid.

99 Usp.: Engel, J., op. cit. u bilj. 3, str. 70.; Peters, B. u: Peters, B. i Schmid-Burgk, K., op. cit. u bilj. 3 , str. 15. Iscrpno o pripisivanju objekta leasinga temeljem koncepta ekonomskog vlasništva u austrijskom i njemačkom pravu vidi u: Tot, I., op. cit. u bilj. 1, str. 130. - 139.

100 MRS 17 uvriježena je kratica za "Međunarodni računovodstveni standard 17 - Najmovi" koji je mjerodavan računovodstveni standard za računovodstva najmova, a time i računovodstvo leasinga. Naime, računovodstveni pojam najam iz t. 4. MRS-a 17 znatno je širi od građanskopravnog pojma ugovora o najmu, a njime je osim ugovora o najmu, ugovora o zakupu i ugovora o leasingu kao pojedinih uobičajenih tipova ugovora o prijenosu prava uporabe obuhvaćen i čitav niz različitih drugih tipova ugovora koji se odnose na vremenski ograničeni naplatni prijenos prava uporabe nekog sredstva u ekonomskom smislu, i to neovisno o tomu je li prijenos prava uporabe nekog sredstva primarna svrha tog ugovora ili ugovor ima neku drugu 
prema nacionalnim računovodstvenim standardima u austrijskom i njemačkom pravu imaju istovjetan računovodstveni tretman koji u sustavu MRS-a 17 imaju ugovori koji se razvrstavaju kao poslovni najmovi. ${ }^{101}$

$\mathrm{Za}$ razliku od austrijskog i njemačkog prava, u hrvatskom pravu je za računovodstvo leasinga ponajprije mjerodavan MRS $17 .{ }^{102}$ Ugovori o operativnom leasingu se u hrvatskoj poslovnoj praksi redovito razvrstavaju kao poslovni najmovi u smislu MRS-a 17, neovisno o tomu je li rizik unovčenja objekta leasinga na davatelju leasinga (kao što je to slučaj u analiziranom modelu ugovora o operativnom leasingu iz hrvatske poslovne prakse koji je usporediv s ugovorom s obračunom kilometraže iz austrijske i njemačke poslovne prakse) ili je rizik unovčenja objeka leasinga na primatelju leasinga (kao što je to slučaj u analiziranom modelu ugovora o operativnom leasingu iz hrvatske poslovne prakse koji je usporediv s ugovorom s obračunom ostatka vrijednosti iz austrijske i njemačke poslovne prakse). Računovodstveni tretman ugovora o operativnom leasingu kao poslovnog najma u smislu MRS-a 17 u osnovi se svodi na to: (i) da se objekt leasinga prikazuje samo u bilanci davatelja leasinga, a ne i u bilanci primatelja leasinga; (ii) da amortizaciju koja predstavlja rashod obračunskog razdoblja obračunava davatelj leasinga; (iii) da u računu dobiti i gubitka primatelj leasinga iskazuje troškove razdoblja po osnovi plaćanja mjesečnih obroka naknade za leasing kao poslovne rashode, dok davatelj leasinga u računu dobiti i gubitka iskazuje financijske prihode te troškove amortizacije kao poslovne rashode. ${ }^{103}$

Ugovori o financijskom leasingu se u hrvatskoj poslovnoj praksi redovito razvrstavaju kao financijski najmovi u smislu MRS-a 17, a takav se računovodstveni tretman ugovora o financijskom leasingu u biti svodi na to: (i) da se objekt leasinga prikazuje i u bilanci primatelja leasinga (kao dugotrajna materijalna imovina i kao dugoročna obveza) i u bilanci davatelja leasinga (kao dugoročno potraživanje); (ii) da amortizaciju koja predstavlja rashod obračunskog razdoblja obračunava primatelj leasinga; (iii) da u računu dobiti i gubitka primatelj leasinga iskazuje troškove amortizacije kao poslovne rashode i troškove financiranja po osnovi plaćanja naknade za leasing kao financijske rashode, dok davatelj leasinga iskazuje financijske prihode. ${ }^{104}$

Ključni kriterij klasifikacije najmova na financijski i poslovni najam, prema t. 7. MRS-a 17, je opseg u kojemu rizike i koristi povezane s vlasništvom predmeta najma snosi najmodavac ili najmoprimac. Financijski najam definiran je t. 4. i 8. MRS-a 17 , kao najam kojim se na najmoprimca prenose gotovo svi rizici i koristi povezani s vlasništvom, pri čemu eventualno može i ne mora doći do prijenosa prava vlasništva. Poslovni najam je, prema t. 4. i 8. MRS-a 17, svaki najam osim financijskog najma, odnosno najam kojim se na najmoprimca ne prenose gotovo svi rizici i koristi povezani $\mathrm{s}$ vlasništvom.

Ugovore o operativnom leasingu u kojima je rizik unovčenja objekta leasinga na davatelju leasingu u pravilu će biti opravdano klasificirati kao poslovne najmove u

svrhu za čije ostvarenje je potrebno i naplatno prenijeti pravo uporabe na nekom sredstvu.

101 Iscrpnije o ovome vidi u: Tot, I., op. cit. u bilj. 1, str. 139. - 148.

102 Ibid., str. 104. - 105.

103 Usp.: ibid., str. 123.

104 Usp.: ibid. 
smislu MRS-a 17, jer oni prema svojim obilježjima ne odgovaraju detaljno razrađenim primjerima slučajeva koji prema odredbama t. 10. MRS-a 17 uobičajeno dovode do klasifikacije ugovora kao financijskog najma, ni pokazateljima slučajeva koji bi prema odredbama t. 11. MRS-a 17 mogli dovesti do klasifikacije ugovora kao financijskog najma. Za ugovore o operativnom leasingu u kojima je rizik unovčenja objekta leasinga na davatelju leasinga redovito je karakteristično: (i) da se vlasništvo nad objektom leasinga ne prenosi na primatelja leasinga po završetku razdoblja leasinga (t. 10.a MRS-a 17); (ii) da primatelj leasinga nema opciju kupnje objekta leasinga po cijeni koja je znatno niža od "fer" vrijednosti objekta leasinga na dan izvršenja opcije (t. 10.b MRS-a 17); (iii) da razdoblje leasinga ne pokriva veći dio ekonomskog vijeka objekta leasinga (t. 10.c MRS-a 17); (iv) da vrijednost minimalnih plaćanja leasinga na početku ugovora ne pokriva gotovo cjelokupnu "fer" vrijednost objekta leasinga (t. 10.d MRS-a 17); (v) da objekt leasinga nije takve posebne prirode da ga samo primatelj leasinga može koristiti bez većih preinaka (t. 10.e MRS-a 17); (vi) da primatelj leasinga može otkazati ugovor o leasingu bez obveze snošenja $\mathrm{s}$ time povezanim gubitaka davatelja leasinga (t. 11.a MRS-a 17); (vii) da se dobitci ili gubitci iz fluktuacija "fer" vrijednosti ostatka vrijednosti ne zaračunavaju primatelju leasinga (t. 11.b MRS-a 17); (viii) da primatelj leasinga nema opciju produženja ugovora o leasinga uz naknadu znatno nižu od tržišne (t. 11.c MRS-a 17).

$S$ druge strane, upitna je opravdanost računovodstvenog tretmana ugovora o operativnom leasingu u kojima je rizik unovčenja objekta leasinga na primatelju leasinga kao poslovnih najmova u smislu MRS-a 17. U takvim ugovorima o operativnom leasingu "gubitke iz fluktuacija fer vrijednosti ostatka vrijednosti", u smislu t. 11.b MRS-a 17, obvezan je davatelju leasinga podmiriti primatelj leasinga, što upućuje na to da bi takav ugovor trebalo računovodstveno klasificirati kao financijski najam, a ne kao poslovni najam. Također, pojam minimalnih plaćanja najma iz t. 4. MRS-a 17 uključuje "za najmodavca, i bilo koji ostatak vrijednosti koji mu jamči najmoprimac ili s njime povezana strana ili strana koja nije povezana s najmodavcem". Stoga i prema testu nadoknade investicije iz t. 10.d MRS-a 17, prema kojemu bi ugovor u redovnom slučaju trebalo označiti financijskim najmom ako vrijednost minimalnih plaćanja najma na početku najma "pokriva gotovo cjelokupnu fer vrijednost iznajmljenog sredstva", proizlazi da bi ugovore o operativnom leasingu u kojima primatelj leasinga jamči za ostatak vrijednosti objekta leasinga trebalo početno razvrstati kao financijske najmove, a ne kao poslovne najmove. ${ }^{105}$

Štoviše, u hrvatskom pravu su posao operativnog i posao financijskog leasinga definirani odredbama čl. 5. st. 2. i 3. ZL-a na način da su kao njihova pojedina razlikovna ekonomska obilježja istaknuta pojedina razlikovna obilježja poslovnog i financijskog najma prema računovodstvenoj klasifikaciji najmova iz MRS-a 17. ${ }^{106}$ To

105 Ibid., str. 300. - 301.

106 Prema odredbi čl. 5. st. 2. ZL-a, ključna ekonomska obilježja posla financijskog leasinga su da primatelj leasinga: (i) "u razdoblju korištenja objekta leasinga plaća davatelju leasinga naknadu koja uzima u obzir cjelokupnu vrijednost objekta leasinga"; (ii) "snosi troškove amortizacije tog objekta leasinga"; (iii) "opcijom kupnje može steći pravo vlasništva nad tim objektom leasinga po određenoj cijeni koja je u trenutku izvršenja te opcije manja od stvarne vrijednosti objekta leasinga u tom trenutku"; te da se na primatelja leasinga (iv) "rizici i koristi povezani s 
je posebno vidljivo iz uporabe izraza "rizici i koristi povezani s vlasništvom na objektu leasinga" u tim odredbama, a što je računovodstveni termin koji rabi MRS 17, kao i iz preuzimanja kriterija opsega u kojem su rizici i koristi povezani s vlasništvom na objektu leasinga preneseni na najmoprimca kao temeljnog kriterija računovodstvene klasifikacije najmova iz MRS-a 17 na poslovni i financijski najam te prihvaćanja tog kriterija odredbama čl. 5. st. 2. i 3. ZL-a kao jednog od razlikovnih kriterija posla operativnog i posla financijskog leasinga.

Stoga upitna opravdanost računovodstvenog tretmana ugovora o operativnom leasingu u kojima je rizik unovčenja objekta leasinga na primatelju leasinga kao poslovnog najma u smislu MRS-a 17 stvara i dvojbe glede toga bi li u kontekstu hrvatskoga pozitivnog prava takve ugovore uopće bilo moguće pravno kvalificirati kao ugovore o operativnom leasingu.

\section{UGOVOR O OPERATIVNOM LEASINGU MOTORNOG VOZILAS PROMJENOM METODE KONAČNOG OBRAČUNA}

Pod nazivom ugovora o operativnom leasingu pronalaze se u hrvatskoj poslovnoj praksi i takvi ugovori o operativnom leasingu motornih vozila u kojima je davatelj leasinga nositelj rizika unovčenja motornog vozila samo u slučaju redovnog isteka ugovora, dok je u slučaju prijevremenog prestanka ugovora taj rizik na primatelju leasinga. Kako se u ovom ugovornom modelu konačni obračun u slučaju redovnog isteka ugovora vrši po metodi karakterističnoj za ugovore s obračunom kilometraže, dok se u slučaju prijevremenog isteka ugovora konačni obračun vrši po metodi karakterističnoj za ugovore s obračunom ostatka vrijednosti, taj se ugovorni model ugovora o operativnom leasingu motornog vozila $u$ ovom radu naziva ugovorom $o$ operativnom leasingu s promjenom metode konačnog obračuna.

Primjerice, odredbama općih uvjeta poslovanja za ugovore o operativnom leasingu jednog hrvatskog leasing društva za slučaj redovnog isteka ugovora ugovorena su sljedeća prava i obveze ugovornih strana: (i) obveza primatelja leasinga vratiti objekt leasinga u ugovorenom stanju; ${ }^{107}$ (ii) pravo davatelja leasinga pregledati objekt leasinga radi utvrđivanja stanja i oštećenja vraćenog objekta leasinga, te procjeniti troškove njihova uklanjanja; ${ }^{108}$ (iii) obveza primatelja leasinga platiti davatelju leasinga naknadu za prekoračenje ugovorene kilometraže ${ }^{109}$ te (iv) obveza primatelja leasinga platiti davatelju leasinga naknadu za smanjenje vrijednosti objekta

vlasništvom na objektu leasinga većim dijelom prenose".

Ključna ekonomska obilježja posla operativnog leasinga, prema odredbi čl. 5. st. 3. ZL-a, su: (i) "primatelj leasinga u razdoblju korištenja objekta leasinga plaća davatelju leasinga određenu naknadu koja ne mora uzimati u obzir cjelokupnu vrijednost objekta leasinga"; (ii) "davatelj leasinga snosi troškove amortizacije tog objekta leasinga"; (iii) "primatelj leasinga nema ugovorenu opciju kupnje" te (iv) "rizici i koristi povezani s vlasništvom na objektu leasinga većim dijelom ostaju na davatelju leasinga, odnosno ne prenose se na primatelja leasinga."

107 Odredbom čl. 20.1. OU PBZ-a primatelj leasinga se obvezuje objekt leasinga vratiti davatelju leasinga "u besprijekornom stanju sukladnom toč. 10. ovih uvjeta".

108 Prema odredbi čl. 20.2. OU PBZ.

109 Prema odredbi čl. 20.3. OU PBZ. 
leasinga. ${ }^{110}$ Među parametrima relevantnim za konačni obračun u slučaju redovnog isteka ugovora nije naznačen ni ostatak vrijednosti objekta leasinga niti iznos postignutom unovčenjem objekta leasinga poslije redovnog isteka ugovora. ${ }^{111}$ Istim odredbama općih uvjeta poslovanja je za slučaj prijevremenog prestanka ugovora jednostranim raskidom izjavljenim od strane davatelja leasinga ugovorena metoda konačnog obračuna prema kojoj se nakon vraćanja objekta leasinga davatelju leasinga ne pristupa pregledu objekta leasinga radi utvrđenja njegova stanja i oštećenja, već se po ovlaštenom sudskom vještaku procjenjuje stvarna vrijednost objekta leasinga, tzv. "neto cijena po procjeni", a ako je ona "niža od ostatka vrijednosti uvećanog za glavnice u nedospjelim obrocima do ugovorenog isteka", za razliku se tereti primatelja leasinga. ${ }^{112}$

Iz analize odredaba tih općih uvjeta poslovanja za ugovore o operativnom leasingu proizlazi da je u slučaju redovnog isteka ugovora o operativnom leasingu rizik unovčenja objekta leasinga na davatelju leasinga, dok je u slučaju prijevremenog isteka ugovora o operativnom leasingu rizik unovčenja objekta leasinga prenesen na primatelja leasinga koji jamči za ostatak vrijednosti objekta leasinga. Odredbe koje su u bitnome istovjetne ovdje analiziranim odredbama sadržane su i u općim uvjetima poslovanja za ugovore o operativnom leasingu većine hrvatskih leasing društava. ${ }^{113}$

Obilježja ovog ugovornog modela ugovora o operativnom leasingu iz hrvatske poslovne prakse dijelom su karakteristična obilježja ugovora s obračunom kilometraže, a dijelom su karakteristična obilježja ugovora s obračunom ostatka vrijednosti iz austrijske i njemačke poslovne prakse. Dijelom ovaj ugovorni model sadrži i bitna odstupanja i od obilježja koja su karakteristična za ugovore s obračunom kilometraže ${ }^{114}$ i od obilježja koja su karakteristična za ugovore s obračunom ostatka vrijednosti u austrijskoj i njemačkoj poslovnoj praksi. ${ }^{115}$

110 Prema odredbi čl. 22.2. OU PBZ-a, u slučaju redovnog isteka ugovora o operativnom leasingu se "utvrđuju vidljivi nedostaci i oštećenja koja nisu pokrivena osiguranjem, te se za njih tereti primatelja leasinga", a jedan od elemenata konačnog obračuna su i "troškovi za otklanjanje vidljivih nedostataka i oštećenja".

111 Prema odredbi čl. 22.2. OU PBZ.

112 Prema odredbama čl. 22.3. OU PBZ.

113 Tako, primjerice, prema odredbama čl. 23.1.1. OU EL-a u konačni obračun u slučaju redovnog isteka ugovora ne ulazi ni ostatak vrijednosti objekta leasinga ni iznos ostvaren unovčenjem objekta leasinga, dok je za slučaj prijevremenog prestanka ugovora ugovoreno odredbom čl. 23.1.2. OU EL-a da će davatelj leasinga "prilikom izrade konačnog obračunskog dopisa u obračun uključiti i procijenjenu vrijednost Objekta leasinga iz članka 20. stavka 3. na način; da će ukupno dugovanje Primatelja leasinga koje se sastoji od svih troškova iz stavka 1. ovog članka, neotplaćenih nedospjelih Obroka leasinga umanjenih za kamatu sadržanu u njima (nenamirena vrijednost po Ugovoru), ugovorenog ostatka vrijednosti Objekta leasinga koji je dužan naplatiti od Primatelja leasinga temeljem Ugovora i ovih Uvjeta, umanjiti za iznos procijenjene vrijednosti Objekta leasinga".

114 Primjerice, ponegdje je odredbama općih uvjeta poslovanja za ugovore o operativnom leasingu hrvatskih leasing društava izričito isključeno bilo kakvo pravo primatelja leasinga u slučaju nedostizanja ugovorene kilometraže, pa tako i odredbama: čl. 25.5. OU-OL IL i čl. 25.5. OURWL IL.

115 Primjerice, općim uvjetima poslovanja za ugovore o operativnom leasingu hrvatskih leasing društava redovito nije ugovoreno pravo primatelja leasinga na udio u višku prihoda ostvarenih 
Analizirana stajališta austrijske i njemačke sudske prakse i pravne književnosti koja se mogu primijeniti u kontekstu hrvatskoga prava na ugovor o operativnom leasingu motornog vozila $\mathrm{u}$ kojemu je davatelj leasinga nositelj rizika unovčenja motornog vozila i na ugovor o operativnom leasingu motornog vozila u kojemu je primatelj leasinga nositelj rizika unovčenja motornog vozila, mogu se na odgovarajući način primijeniti u kontekstu hrvatskoga prava i na ugovor o operativnom leasingu motornog vozila s promjenom metode konačnog obračuna. Valja upozoriti da je zbog kombinacije različitih metoda obračuna u istom ugovornom modelu moguće $i$ da bi davatelji leasinga kumulativno isticali zahtjeve koji se međusobno isključuju. Primjerice, u slučaju prijevremenog prestanka ugovora o operativnom leasingu sklopljenog u modelu ugovora s promjenom metode konačnog obračuna, davatelj leasinga ne bi opravdano mogao, uz zahtjev za naknadu razlike između nižeg iznosa postignutom unovčenjem objekta leasinga i višeg iznosa ugovorenog ostatka vrijednosti, istaknuti primatelju i zahtjev za naknadom za prekoračenje ugovorene kilometraže - jer je smanjenje vrijednosti motornog vozila zbog prekoračenja ugovorene kilometraže davatelju leasinga nadoknađeno putem naknade razlike između navedenih iznosa. ${ }^{116}$

Posebno je pitanje može li se općim uvjetima poslovanja uopće valjano ugovoriti promjena metode obračuna za slučaj prijevremenog prestanka ugovora o operativnom leasingu motornog vozila. Prema stajalištu njemačke sudske prakse i pravne književnosti, ugovorna odredba sadržana u općim uvjetima poslovanja za ugovor s obračunom kilometraže temeljem koje se, u slučaju prijevremenog prestanka ugovora, metoda konačnog obračuna karakteristična za ugovor s ograničenjem kilometraže zamjenjuje s metodom konačnog obračuna karakterističnom za ugovor s obračunom ostatka vrijednosti, je neočekivana ugovorna odredba koja ne proizvodi pravne učinke. ${ }^{117}$ I ovdje iz zahtjeva transparentnosti proizlazi da bi takva promjena metode obračuna bila valjana samo ako bi u ispravi ugovora o leasingu bila istaknuta jasna naznaka o promjeni metode obračuna u slučaju prijevremenog prestanka ugovora i obvezama primatelja leasinga u tom slučaju. ${ }^{118} \mathrm{Tu}$ bi okolnost trebala uzeti

prodajom objektom leasinga, a ponegdje je i izričito ugovoreno da je davatelj leasinga ovlašten zadržati cjelokupni iznos tog viška, pa tako i odredbama: čl. 12.6. OU SG.

$116 \mathrm{U}$ bitnome istovjetno je istaknuto i u odlukama iz njemačke sudske prakse: BGH, VIII ZR 208/00 od 9. svibnja 2001., dostupno na: openJur, 8. siječnja 2017., § 30.; OLG Düsseldorf, I-24 U 111/11 od 15. prosinca 2011., dostupno na: openJur, 8. siječnja 2017., § 47.

117 Ovo stajalište u njemačkoj sudskoj praksi izraženo je u odlukama: BGH, VIII ZR 319/85 od 15. listopada 1986., dostupno na: Jurion, 8. siječnja 2017., § 29.; BGH, VIII ZR 367/03 od 14. srpnja 2004., dostupno na: openJur, 8. siječanj 2017., § 28.; OLG Düsseldorf, I-24 U 44/05 od 22. studenog 2005., dostupno na: openJur, 8. siječanj 2017., § 43.; OLG Düsseldorf, I-24 U 208/08 od 29. lipnja 2009., dostupno na: openJur, 8. siječnja 2017., § 20. U austrijskoj i njemačkoj pravnoj književnosti istovjetno u: Berninghaus, J. u: Büschgen, H. E., op. cit. u bilj. 3, str. 397.; Engel, J., op. cit. u bilj. 3, str. 283.; Godefroid, C., loc. cit. u bilj. 28; Koch, J. u: MünchKomm III, op. cit. u bilj. 3, Rn. 136.; Martinek, M. i Wimmer-Leonhardt, S. u: Martinek et al., loc. cit. u bilj. 34; Peters, B. u: Peters, B. i Schmid-Burgk, K., op. cit. u bilj. 3, str. 92. i 98.; Schopper, A. i Skarics, F. u: Apathy, P. et al., op. cit. u bilj. 3, str. 98.; Zahn, H. u: Graf von Westphalen, F., op. cit. u bilj. 3, str. 947.

118 Usp.: Engel, J., op. cit. u bilj. 3, str. 75.; Martinek, M. i Wimmer-Leonhardt, S. u: Martinek et al., loc. cit. u bilj. 34; Peters, B. u: Peters, B. i Schmid-Burgk, K., op. cit. u bilj. 3, str. 92. 
u obzir i hrvatska sudska praksa pri ispitivanju valjanosti odredaba o metodi konačnog obračuna u slučaju prijevremenoga prestanka ugovora o operativnom leasingu.

\section{ZAKLJUČAK}

Pod nazivom ugovora o operativnom leasingu motornog vozila pronalaze se u hrvatskoj poslovnoj praksi različiti modeli ugovora o operativnom leasingu koji se bitno razlikuju u pogledu metode konačnog obračuna nakon prestanka ugovora $\mathrm{i}$ s time povezanog pitanja raspodjele rizika unovčenja motornog vozila. Samo je za jedan od tih ugovornih modela, $i$ to onaj u kojemu je rizik unovčenja motornog vozila isključivo na davatelju leasinga, sasvim neupitno da je riječ o ugovoru sklopljenom u okviru posla operativnog leasinga i u računovodstvenom i u obveznopravnom pogledu. Drugi ugovorni modeli ugovora o operativnom leasingu iz hrvatske poslovne prakse, u kojima je rizik unovčenja motornog vozila prenesen na primatelja leasinga bilo za slučaj prijevremenog prestanka ugovora, bilo i u slučaju redovnog isteka ugovora, pokazuju izvjesne sličnosti s ugovornim modelima ugovora o financijskom leasingu.

Pitanje raspodjele rizika unovčenja motornog vozila nakon prestanka ugovora o operativnom leasingu nije u hrvatskom pravu uređeno zakonom, a u objavljenoj hrvatskoj sudskoj praksi ne postoji stajalište o tom pitanju, niti je to pitanje bilo predmetom interesa hrvatske pravne književnosti. Stoga se u ovom radu nastojalo analizom različitih modela ugovora o operativnom leasingu iz hrvatske poslovne prakse te istraživanjem austrijskog i njemačkog prava ponuditi odgovore na pojedina obveznopravna pitanja koja se odnose na obveze primatelja leasinga prema davatelju leasinga nakon prestanka ugovora o operativnom leasingu motornog vozila i vraćanja motornog vozila davatelju leasinga. Ugovorni modeli ugovora o operativnom leasingu motornih vozila iz hrvatske poslovne prakse u znatnoj su mjeri prema svojim obilježjima usporedivi s dva najčešća ugovorna modela ugovora o leasingu motornih vozila iz austrijske i njemačke poslovne prakse. Utvrđena zajednička obilježja ugovornih modela i bliskost hrvatskoga obveznog prava austrijskom i njemačkom obveznom pravu, omogućavaju i opravdavaju da se pojedina rješenja ustanovljena u austrijskoj i njemačkoj sudskoj praksi i pravnoj književnosti primijene na odgovarajući način na ugovore o operativnom leasingu motornih vozila i u okvirima hrvatskoga pozitivnog prava.

Rad se suzdržao od predlaganja promjena zakonodavnog uređenja prava i obveza ugovornih strana ugovora o operativnom leasingu de lege ferenda. Razlog tomu jest taj što se ocijenilo da se hrvatska poslovna praksa na tržištu leasinga još uvijek razvija te da se nisu svi pojavni oblici ugovora o leasingu ustalili i tipizirali u tolikoj mjeri da bi bilo svrhovito obveznopravne odnose među sudionicima posla leasinga $i$ njegovih pojavnih oblika urediti zakonom u znatnijem opsegu u odnosu na postojeće pozitivnopravno uređenje. Na značajniju neravnotežu prava i obveza ugovornih strana ugovora o operativnom leasingu može se i bez zakonodavne intervencije reagirati putem sudskog mehanizma zaštite od nepoštenih ugovornih odredbi. 


\section{LITERATURA}

\section{A. Knjige}

1. Beckmann, Heiner i Scharff, Uwe, Leasingrecht - Rechtsprobleme beim Finanzierungsleasing, Verlag C.H. Beck, München, 2015.

2. Büschgen, Hans E. (ur.), Praxishandbuch Leasing, C. H. Beck'sche Verlagsbuchhandlung, München, 1998.

3. Egger, Anton i Krejci, Heinz (ur.), Das Leasinggeschäft - Zivil-, Bilanz- und Steuerrecht, Betriebswirtschaft und Praxis, Wirtschaftsverlag Dr. Anton Orac, Wien, 1987.

4. Engel, Johanne, Handbuch Kraftfahrzeugleasing, Verlag C.H. Beck, München, 2015.

5. Fink, Claudia, Bewertungstheoretische Grundlagen der Leasingfinanzierung - Rechtliche Rahmenbedingungen in Österreich, Springer - Gabler, Wiesbaden, 1997.

6. Fischer-Czermak, Constanze, Mobilienleasing - Rechtsnatur, Gewährleistung und Gefahrtragung, Manzsche Verlags- und Universitätsbuchhandlung, Wien, 1995.

7. Graf von Westphalen, Friedrich (ur.), Der Leasingvertrag, Verlag Dr. Otto Schmidt, Köln, 2015.

8. Grundmann, Wolfgang, Leasing und Factoring - Formen, Rechtsgrundlagen, Verträge, Springer - Gabler, Wiesbaden, 2013.

9. Honal, Martin, Loss Given Default von Mobilien-Leasingverträgen, Gabler Verlag, Wiesbaden, 2009.

10. Kaiser, Dagmar (red.), J. von Staudingers Kommentar zum Bürgerlichen Gesetzbuzch mit Einführungsgesetz und Nebengesetzen - Buch 2 - Recht der Schuldverhältnisse Leasing (Leasingrecht) - Neubearbeitung 2014 von Markus Stoffels, Sellier - de Gruyter, Berlin, 2014.

11. Kratzer, Jost i Kreuzmair, Benno, Leasing in Theorie und Praxis, Gabler Verlag, Wiesbaden, 2002.

12. Martinek, Michael, Stoffels, Markus i Wimmer-Leonhardt, Susanne (ur.), Handbuch des Leasingrechts, Verlag C.H. Beck, München, 2008.

13. Oechsler, Jürgen, Schuldrecht - Besonderer Teil - Vertragsrecht, Verlag Franz Vahlen, München, 2003.

14. Peters, Bernd i Schmid-Burgk, Klaus, Das Leasinggeschäft, Bank-Verlag Medien, Köln, 2011

15. Schimmelschmidt, Uwe, Finanzierungsleasing: eine EDV-gestützte Vorteilhaftigkeitsanalyse, Gabler Verlag, Wiesbaden, 1994.

16. Tot, Ivan, Operativni leasing, doktorski rad, Pravni fakultet Sveučilišta u Zagrebu, Zagreb, 2016.

B. Članci i poglavlja u knjizi

1. Baretić, Marko i Markovinović, Hrvoje, Nepoštene ugovorne odredbe - opće i posebna uređenja, u: Barbić, Jakša i Giunio, Miljenko (ur.), Zbornik 50. jubilarnog susreta pravnika Opatija 2012., Hrvatski savez udruga pravnika u gospodarstvu, Zagreb, 2012., str. 57. - 132.

2. Godefroid, Christoph, Kraftfahrzeugleasingverträge mit Kilometerabrechnung und $\S 506$ BGB, Straßenverkehrsrecht - die Zeitschrift für die Praxis des Verkehrsjuristen, vol. 13, 5/2013, str. 161. - 167.

3. Goldkamp, Tobias i Reimer, Nadine, Die leasingtypischen Ausgleichsansprüche bei Fahrzeugrückgabe im Rahmen eines Leasingvertrags, Juris - die Monatszeitschrift, vol. 1, 8-9/2014, str. 321. - 326.

4. Gonzales del Campo, Federico, Neue Vertragsformen als Rechtstransfer? Zum Topos der angloamerikanischen Provenienz des Leasing-Rechts, Rechtsgeschichte: Zeitschrift des Max-Planck-Instituts für Europäische Rechtsgeschichte, vol. 7, 7/2005, str. 46. - 57. 
5. Josipović, Tatjana, Financial leasing in Croatia, Uniform Law Review, vol. 16, 1-2/2011, str. 271. - 289.

6. Keglević, Ana, Ugovor o leasingu - novi imenovani ugovor hrvatskog prava, u: Gliha, Igor, Josipović, Tatjana, Belaj, Vladimir, Baretić, Marko, Nikšić, Saša, Ernst, Hano, Keglević, Ana i Matanovac, Romana (ur.), Liber amicorum Nikola Gavella - Građansko pravo u razvoju, Pravni fakultet Sveučilišta u Zagrebu, Zagreb, 2007., str. 607. - 657.

7. Koch, Jens, Finanzierungsleasing, u: Krüger, Wolfgang i Westermann, Harm Peter (red.), Münchener Kommentar zum Bürgerlichen Gesetzbuch - Band 3 - Schuldrecht - Besonderer Teil - §§ 433 - 610, Verlag C. H. Beck, München, 2012., str. 980. - 1065.

8. Miladin, Petar, Razgraničenje između klauzula o ugovornoj kazni i klauzula s paušaliziranim zahtjevima za naknadom štete, Zbornik Pravnog fakulteta u Zagrebu, vol. 52, 2/2002, str. 385. - 421.

9. Parać, Zoran, Zakon o leasingu (ili što je to pjesnik stvarno htio reći), Pravo u gospodarstvu, vol. 46, 4/2007, str. 147. - 184.

10. Pešutić, Andrea, Ugovor o leasingu, u: Slakoper, Zvonimir (ur.), Bankovni i financijski ugovori, Pravni fakultet Sveučilišta u Rijeci, Rijeka, 2007., str. 1007. - 1029.

11. Riedler, Andreas, Bestandvertrag, u: Apathy, Peter i Riedler, Andreas, Bürgerliches Recht - Band III - Schuldrecht - Besonderer Teil, Springer, Wien - New York, 2010., str. 70. - 126.

12. Schopper, Alexander i Skarics, Florian, Das Leasinggeschäft, u: Apathy, Peter, Iro, Gert i Koziol, Helmut (ur.), Österreichisches Bankvertragsrecht - Band VII: Leasing, Factoring und Forfaitierung, Verlag Österreich, Wien, 2015., str. 1. - 216.

C. Pravni akti

1. Hrvatska agencija za nadzor financijskih usluga, Pravilnik o sadržaju i obliku ugovora o leasingu te metodologiji izračuna efektivne kamatne stope, $\mathrm{NN}$ br. 66/14.

2. Zakon o leasingu, NN br. 135/06.

3. Zakon o leasingu, $\mathrm{NN}$ br. 141/13.

4. Zakon o obveznim odnosima, NN br. 35/05., 41/08., 125/11. i 78/15.

D. Sudska praksa

D.1. Austrija, Republika

1. Oberster Gerichtshof, 8 Ob 38/90 od 17. siječnja 1991., dostupno na: Bundeskanzleramt - Rechtsinformationssystem, <https://www.ris.bka.gv.at/>, 8. siječanj 2017.

2. Oberster Gerichtshof, $7 \mathrm{Ob} 230 / 08 \mathrm{~m}$ od 13. svibnja 2009., dostupno na: Bundeskanzleramt - Rechtsinformationssystem, <https://www.ris.bka.gv.at/>, 8. siječanj 2017.

D.2. Hrvatska, Republika

1. Općinski sud u Samoboru, Povrv-1691/12 od 6. lipnja 2014. (neobjavljena)

2. Trgovački sud u Zagrebu, P-481/2013 od 7. srpnja 2014. (neobjavljena)

3. Županijski sud u Bjelovaru, Gž-2540/11-3 od 1. ožujka 2012., dostupno na: Portal IUSINFO, < http://www.iusinfo.hr/>, 7. siječanj 2017.

D.3. Njemačka, Savezna Republika

1. Bundesgerichtshof, VIII ZR 148/84 od 12. lipnja 1985., dostupno na: Jurion - das Rechtsportal, < https://www.jurion.de/>, 8. siječanj 2017.

2. Bundesgerichtshof, VIII ZR 319/85 od 15. listopada 1986., dostupno na: Jurion - das Rechtsportal, < https://www.jurion.de/>, 8. siječanj 2017.

3. Bundesgerichtshof, VIII ZR 296/89 od 10. listopada 1990., dostupno na: Jurion - das Rechtsportal, < https://www.jurion.de/>, 8. siječanj 2017.

4. Bundesgerichtshof, VIII ZR 39/91 od 27. studenog 1991., dostupno na: Jurion - das Rechtsportal, < https://www.jurion.de/>, 8. siječanj 2017.

5. Bundesgerichtshof, BGH, VIII ZR 312/96 od 4. lipnja 1997., dostupno na: Jurion - das 
Rechtsportal, < https://www.jurion.de/>, 8. siječanj 2017.

6. Bundesgerichtshof, VIII ZR 177/99 od 1. ožujka 2000., dostupno na: openJur, 8. siječanj 2017.

7. Bundesgerichtshof, VIII ZR 208/00 od 9. svibnja 2001., dostupno na: openJur, 8. siječanj 2017.

8. Bundesgerichtshof, VIII ZR 367/03 od 14. srpnja 2004., dostupno na: openJur - die freie juristische Datenbank, < https://openjur.de/>, 8. siječanj 2017.

9. Bundesgerichtshof, VIII ZR 22/12 od 14. studenog 2012., dostupno na: openJur - die freie juristische Datenbank, < https://openjur.de/>, 8. siječanj 2017.

10. Bundesgerichtshof, III ZR 265/12 od 24. travnja 2013., dostupno na: openJur - die freie juristische Datenbank, < https://openjur.de/>, 8. siječanj 2017.

11. Bundesgerichtshof, VIII ZR 336/12 od 24. travnja 2013., dostupno na: openJur - die freie juristische Datenbank, < https://openjur.de/>, 8. siječanj 2017.

12. Bundesgerichtshof, VIII ZR 334/12 od 17. srpnja 2013., dostupno na: openJur - die freie juristische Datenbank, < https://openjur.de/>, 8. siječanj 2017.

13. Oberlandesgerichtshof Dresden, 8 U 339/00 od 28. lipnja 2000., dostupno na: Judicialis - Rechtsprechung, <http://www.judicialis.de/>, 8. siječanj 2017.

14. Oberlandesgerichtshof Düsseldorf, I-24 U 44/05 od 22. studenog 2005., dostupno na: openJur - die freie juristische Datenbank, $<$ https://openjur.de/>, 8. siječanj 2017.

15. Oberlandesgerichtshof Düsseldorf, I-24 U 208/08 od 29. lipnja 2009., dostupno na: openJur - die freie juristische Datenbank, < https://openjur.de/>, 8. siječanj 2017.

16. Oberlandesgerichtshof Düsseldorf, -24 U 111/11 od 15. prosinca 2011., dostupno na: openJur - die freie juristische Datenbank, < https://openjur.de/>, 8. siječanj 2017.

17. Oberlandesgerichtshof Karlsruhe, 6 U 139/84 od 23. travnja 1986., dostupno na: Jurion - das Rechtsportal, < https://www.jurion.de/>, 8. siječanj 2017.

E) Poslovna praksa

1. ALD Automotive d.o.o., Opći uvjeti ugovora o operativnom leasingu od 16.01.2016., $<$ http://www.aldautomotive.hr/Portals/croatia/adam/Content/xmOvRU3M8kOO9etV4 WtTA/Link_Url/GTB\%20ALD\%20Automotive\%20Cro_2016_01\%20Final.pdf>, 7. siječanj $201 \overline{7}$.

2. ALD Automotive d.o.o., Upute za korisnika, <http://www.aldautomotive.hr/Portals/ croatia/adam/Content/Bz6fDBAwPUyZW0TE7ZCkGg/Free_Text/UPUTA\%20ZA\%20 KORISNIKE-1-2-3.pdf>, 7. siječanj 2017.

3. BKS - leasing Croatia d.o.o., Opći uvjeti ugovora o operativnom leasingu motornog vozila/pokretnine, 1.9.2016., <http://www.bks-leasing.hr/BKSWebp/BKS/Informati onsobjekte/PDFs/HR_Leasing/AGB/Opci_uvjeti_OPERATIVNI_POKRETNINE.pdf>, 7. siječanj 2017.

4. Erste \& Steiermärkische S-Leasing d.o.o., Opći uvjeti uz ugovore o operativnom leasingu broj OL-07000, 11.11.2015., <https://www.ersteleasing.hr/content/dam/hr/el/ www.ersteleasing.hr/dokumentacija/opci-uvjeti-i-naknade/opci-uvjeti-uz-ugovore-ooperativnom-leasingu.pdf>, 7. siječanj 2017.

5. EUROLEASING d.o.o., Opći uvjeti ugovora o operativnom leasingu br. 01/15, studeni 2015., <http://www.euroleasing.hr/downloads.aspx>, 7. siječanj 2017.

6. HYPO - LEASING STEIERMARK d.o.o., Opći uvjeti ugovora o operativnom leasingu pokretnina 10/2011-IV, 1.10.2011., <http://leasing.hypobank.at/hr/pub/ document/?id=237\&doc=1756-20160122-121514-opci_uvjeti_ol_iv.pdf\&typ=pdf $>, \quad 7$. siječanj 2017.

7. IMPULS-LEASING d.o.o., Opći uvjeti poslovanja društva IMPULS - LEASING d.o.o. za sklapanje ugovora o operativnom leasingu OL 0115 07, <http://www.impuls-leasing. $\mathrm{hr} /$ UserDocsImages/dokumenti/Op\%C4\%87i\%20uvjeti\%20operativni\%20leasing\% 
20verzija\%2007.pdf $>$, 7. siječanj 2017.

8. IMPULS - LEASING d.o.o., Opći uvjeti poslovanja društva IMPULS - LEASING d.o.o. za sklapanje ugovora o operativnom leasingu s ugovorenom visinom ostatka vrijednosti RWL 0115 07, <http://www.impuls-leasing.hr/UserDocsImages/ dokumenti/ Op\%C4\%87i\%20uvjeti\%20operativni\%20leasing\%20s\%20ugovorenom\%20 visinom\%20ostatka\%20vrijednosti\%20verzija\%2007.pdf>, 7. siječanj 2017.

9. OTP Leasing d.d., Opći uvjeti ugovora o operativnom leasingu vozila, opreme i drugih pokretnina OL-POK-06, <http://www.otpleasing.hr/UserDocsImages/pdf/ Op\%C4\%87i\%20uvjeti\%20ugovora\%20o\%20operativnom\%201easingu $\% 20$ OLPOK-06.pdf>, 7. siječanj 2017.

10. Porsche leasing d.o.o., Potvrda o predaji vozila, <http://www.porscheleasing.com.hr/ media/Kwc_Basic_DownloadTag_Component/285-10417-2651-10420-linkTag-child/ default/12aaad1c/1477652764/pl_potvrda_predaja_vozila_20_10_2016.pdf>, 7. siječanj 2017.

11. PBZ-LEASING d.o.o., Opći uvjeti PBZL-a za ugovor o operativnom leasingu: v.16.04, 11.4.2016., <http://www.pbz-leasing.hr/media/1077/op_i_uvjeti_pbzl-a_za_ugovor_o_ operativnom_leasingu_v_1604_vozilo_plovilo_oprema.pdf>, 7. siječanj 2017.

12. Raiffeisen Leasing d.o.o., Opći uvjeta ugovora o operativnom leasingu 02_16, 15.2.2016., <http://www.rl-hr.hr/UserDocsImages/OP\%C4\%86I\%20UVJETI\%20-\%20 OPERATIVNI\%20LEASING.pdf>, 7. siječanj 2017.

13. SG Leasing d.o.o., Opći uvjeti operativnog leasinga, 28.7.2016., <http://www.sgleasing. hr/wp-content/uploads/2016/12/Opci-uvjeti-OL-2016-07-28-v2.pdf>, 7. siječanj 2017.

F) Ostalo

1. Hrvatska agencija za nadzor financijskih usluga, Godišnje izvješće 2015., <http://www. hanfa.hr/getfile/44255/Godisnje\%20izvjesce\%202015_web.pdf>, 7. siječanj 2017.

2. Hrvatska agencija za nadzor financijskih usluga, Mjesečni izvještaj - studeni 2016., $<$ http://www.hanfa.hr/getfile/44380/mi\%2012_16.xlsx>, 1. siječanj 2017. 
Summary

\section{RESIDUAL VALUE RISK IN AUTOMOTIVE OPERATING LEASE CONTRACTS}

The subject of the research in this paper are automotive operating lease contracts in the Croatian business practice. The provisions of the general terms and conditions for operating lease contracts of the Croatian leasing companies are being analysed, particulary those relating to the rights and obligations of the parties to the contract after the operating lease contract was terminated and the motor vehicle returned to the lessor. The existence of three contractual models of the automotive operating lease contract in the Croatian business practice is established, which vary with regard to the assignment and the distribution of the residual value risk. Those contractual models are being compared with the two most common contractual models of automotive lease contracts in the Austrian and German business practice: the lease contract with the excess mileage adjustment and the lease contract with the terminal rent adjustment. On the basis of the results of this comparison, applicability of the legal solutions, developed in the Austrian and German jurisprudence and legal literature regarding the lease contract with the excess mileage adjustment and the lease contract with the terminal rent adjustment, to the automotive operating lease contract within the framework of Croatian law, is being examinded.

Keywords: operating lease, automotive leasing, residual value risk, residual value, excess mileage adjustment, terminal rent adjustment.

Zusammenfassung

\section{VERWERTUNGSRISIKO IN DEN OPERATING- KRAFTFAHRZEUG-LEASINGVERTRÄGE}

Der Gegenstand diese Arbeit sind Operating-Leasingverträge in der kroatischen Geschäftspraxis. Die Bestimmungen der allgemeinen Geschäftsbedingungen für Operating-Leasingverträge der kroatischen Leasinggesellschaften werden analysiert, insbesondere in Bezug auf die Rechte und Pflichten der Vertragspartner, nachdem der Operating-Leasingvertrag beendet wurde und das Kraftfahrzeug an den Leasinggeber zurückgesandt wurde. In der kroatischen Geschäftspraxis werden drei vertragliche Modelle des Kraftfahrzeug-Operating-Leasingvertrags festgelegt, die sich hinsichtlich derZuordnungundderVerteilung desRestwertrisikosunterscheiden. Diesevertraglichen Modelle werden mit den beiden gängigsten Vertragsmodellen von KraftfahrzeugLeasingverträgen in der österreichischen und deutschen Geschäftspraxis verglichen: dem Kilometerabrechnungsvertrag und dem Restwertabrechnungsvertrag. Auf Basis der Ergebnisse dieses Vergleichs wird die Anwendbarkeit der in der österreichischen 
und deutschen Rechtslehre und Rechtsliteratur erarbeiteten Rechtslösungen auf den Kilometerabrechnungsvertrag und den Restwertabrechnungsvertrag auf den Operating-Leasingvertrag für Kraftfahrzeuge angewendet im Rahmen des kroatischen Rechtes.

Schlüsselwörter: Operating-Leasing, Kraftfahrzeugleasing, Verwertungsrisiko, Restwert, Kilometerabrechnungsvertrag, Restwertabrechnungsvertrag.

Riassunto

\section{IL RISCHIO DELLA RISCOSSIONE DELL'OGGETTO DI LEASING NEL CONTRATTO DI LEASING OPERATIVO PER VEICOLI A MOTORE}

Il lavoro si propone di esaminare il contratto di leasing operativo per veicoli a motore nella prassi commerciale croata. Si analizzano le disposizioni sulle condizioni generali del contratto di leasing operativo delle società croate di leasing, in particolare quelle che si riferiscono ai diritti ed ai doveri delle parti contrattuali al termine del contratto di leasing operativo e nel momento delle restituzione del veicolo a motore al concedente. Si constata l'esistenza di tre modelli di contratto di leasing operativo per veicoli a motore nella prassi commerciale croata, i quali si differenziano gli uni dagli altri in base al criterio di trasferimento e di ripartizione del rischio di riscossione del valore del veicolo a motore. Tali modelli contrattuali vengono confrontati con i due modelli contrattuali più frequenti di leasing per veicoli a motore nella prassi commerciale austriaca e tedesca: il contratto con il conteggio dei chilometri percorsi ed il contratto con il calcolo del valore residuo. Sulla base dei risultati di tale paragone, si pone la questione dell'applicabilità delle singole soluzioni giuridiche, sviluppate nella giurisprudenza austriaca e tedesca e nella dottrina relativa al contratto che conteggia $\mathrm{i}$ chilometri percorsi ed il contratto che calcola il valore residuo, al contratto di leasing operativo per veicoli a motore nell'ambito del diritto croato.

Parole chiave: leasing operativo, leasing per veicoli a motore, il rischio della riscossione, valore residuo, contratto con il conteggio dei chilometri percorsi, contratto con il calcolo del valore residuo. 
